\title{
1 Contribution of microbial photosynthesis to peatland carbon uptake along a 2 latitudinal gradient
}

3

4 Samuel Hamard ${ }^{1 *}$, Regis Céréghino ${ }^{1}$, Maialen Barret ${ }^{1}$, Anna Sytiuk ${ }^{1}$, Enrique Lara ${ }^{2}$, Ellen Dorrepaal ${ }^{3}$, 5 Paul Kardol ${ }^{4}$, Martin Küttim ${ }^{5}$, Mariusz Lamentowicz ${ }^{6}$, Joséphine Leflaive ${ }^{1}$, Gaël le Roux ${ }^{1}$, Eeva-Stiina 6 Tuittila $^{7}$, Vincent E.J. Jassey ${ }^{1}$

7

1 Laboratoire Ecologie Fonctionnelle et Environnement, Université de Toulouse, UPS, CNRS, Toulouse, France,

2 Real Jardín Botánico de Madrid, CSIC, Plaza de Murillo 2, 28014 Madrid, Spain,

3 Climate Impacts Research Centre, Department of Ecology and Environmental Science, Umeå University, SE-981 07, Abisko, Sweden,

4 Department of Forest Ecology and Management, Swedish University of Agricultural Sciences, 90183 Umeå, Sweden,

5 Institute of Ecology, School of Natural Sciences and Health, Tallinn University, Uus-Sadama 5, 10120 Tallinn, Estonia,

6 Climate Change Ecology Research Unit, Faculty of Geographical and Geological Sciences, Adam Mickiewicz University in Poznan, Bogumiła Krygowskiego 10, 61-680 Poznan, Poland, 7 School of Forest Sciences, Joensuu campus, University of Eastern Finland, Finland.

*corresponding author:

Samuel Hamard

University of Toulouse III - Paul Sabatier

Bâtiment 4R1 / Bureau 344

118 route de Narbonne, 31000 Toulouse

phone: +33561558913

email : samuel.hamard@univ-tlse3.fr 
1. Phototrophic microbes, also known as micro-algae, display a high abundance in many terrestrial surface soils. They contribute to atmospheric carbon dioxide fluxes through their photosynthesis, and thus regulate climate similar to plants. However, microbial photosynthesis remains overlooked in most terrestrial ecosystems. Here, we hypothesize that phototrophic microbes significantly contribute to peatland $\mathrm{C}$ uptake, unless environmental conditions limit their development and their photosynthetic activity.

2. To test our hypothesis, we studied phototrophic microbial communities in five peatlands distributed along a latitudinal gradient in Europe. By means of metabarcoding, microscopy and cytometry analyses, as well as measures of photosynthesis, we investigated the diversity, absolute abundance and photosynthetic rates of the phototrophic microbial communities.

3. We identified 351 photosynthetic prokaryotic and eukaryotic operational taxonomic units (OTU) across the five peatlands. We found that water availability and plant composition were important determinants of the composition and the structure of phototrophic microbial communities. Despite environmental shifts in community structure and composition, we showed that microbial C-fixation rates remained similar along the latitudinal gradient. Our results further revealed that phototrophic microbes accounted for approximately $10 \%$ of peatland C uptake.

4. Synthesis. Our findings show that phototrophic microbes are extremely diverse and abundant in peatlands. While species turnover with environmental conditions, microbial photosynthesis similarly contributed to peatland $\mathrm{C}$ uptake at all latitudes. We estimate that phototrophic microbes take up around $75 \mathrm{MT} \mathrm{CO}_{2}$ per year in northern peatlands. This amount roughly equals the magnitude of projected peatland $\mathrm{C}$ loss due to climate warming and highlight the importance of phototrophic microbes for the peatland C cycle. 


\section{KEYWORDS}

Algae, Carbon cycle, Metabarcoding, Microbial diversity, Peatland, Photosynthesis, Phototrophs, Primary productivity.

\section{INTRODUCTION}

Microbes only represent one-sixth of the living biomass on Earth (93 PgC for fungi, protists, bacteria and archaea; Bar-On et al., 2018) but they drive some of the most important carbon (C) fluxes at the global scale (Caron et al., 2017; Fierer, 2017; Singh et al., 2010). For instance, oceanic phytoplankton contributes to one third of the global photosynthetic $\mathrm{CO}_{2}$ fixation with $50 \mathrm{PgC}$ fixed each year, while the remaining amount is consensually attributed to terrestrial plants (Ciais et al., 2013). The input of organic matter to oceanic and terrestrial food webs is therefore attributed to the photosynthetic activity of either oceanic phytoplankton or terrestrial plants, respectively (Krumins et al., 2013; Liang et al., 2017; Worden et al., 2015). This consensus, however, ignores terrestrial photosynthetic microorganisms also known as micro-algae (hereafter, phototrophic microbes), which are natural components of the soil flora (Bates et al., 2013; Cano-Díaz et al., 2019; Oliverio et al., 2020), and can reach several millions of individuals per gram of soil (Zancan et al., 2006).

Soil phototrophic microbes display myriads of species with a wide range of morphologies and life styles (Caron et al., 2017; Delgado-Baquerizo et al., 2018; Oliverio et al., 2020). Prokaryotes and eukaryotes that compose the soil phototrophic microbial communities can be either photo-autotrophs (i.e., strict phototrophs using only mineral $\mathrm{C}$ as $\mathrm{C}$ source), photo-heterotrophs (i.e., using only organic C; Geisen et al., 2018; Lynn et al., 2017), or mixotrophs (i.e., using both mineral and organic C; Mitra et al., 2016). Recent studies suggest that phototrophic microbes could account for large amounts of net primary production, and play a much larger role in terrestrial $C$ dynamics than previously acknowledged (Elbert et al., 2012). However, our understanding of their contribution to the $C$ balance and productivity of terrestrial ecosystems is largely restricted to drylands (Elbert et al., 2012; Maier et 
al., 2018). Phototrophic microbial contribution to total C fixation remains largely unexplored in most other ecosystems, especially in C-accreting systems such as peatlands.

Peatlands play an important role in the global C cycle as they are major C sinks and store a large pool of soil C (500 - 1000 PgC; Bridgham et al., 2006; Nichols \& Peteet, 2019; Yu, 2012). Peat mosses (i.e., Sphagnum spp.) serve a variety of key functions in peatlands, notably primary production and C sequestration (Turetsky, 2003; van Breemen, 1995). Sphagnum mosses also provide a habitat for a large diversity of microbes living either inside or at the surface of Sphagnum leaves (Gilbert et al., 1998). This association between Sphagnum mosses and microbes forms the bryosphere (Lindo \& Gonzalez, 2010). Sphagnum-associated phototrophic microbes include bacteria (e.g., Cyanobacteria, Alphaproteobacteria), protists (e.g., Chlorophyta) and other mixotrophic micro-eukaryotes (e.g., many Ochrophyta or endosymbiotic Lobosa) (Gilbert et al., 1998; Gilbert \& Mitchell, 2006; Jassey et al., 2015; Lara et al., 2011; Tian et al., 2019) and can be highly abundant. For instance, the biomass of

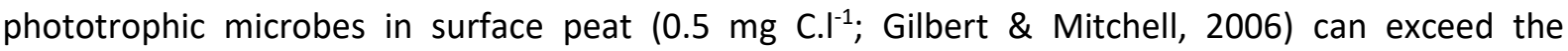

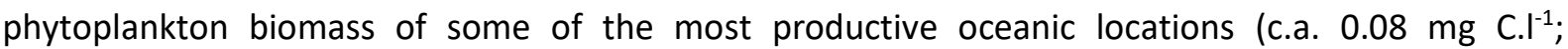
Behrenfeld, 2014). Yet, despite such high abundance, only a handful studies focused on algal productivity in peatlands, mostly in water-logged rich fens (Gilbert et al., 1998; Goldsborough \& Robinson, 1996; Wyatt et al., 2012). Phototrophic microbial productivity remains largely overlooked in all other peatland types including Sphagnum-dominated bogs and poor fens, which constitute the largest part of peatlands at a global scale (Hugelius et al., 2020). Sphagnum-dominated peatlands occupy extensive areas of land at different latitudes and across a wide variety of climates (Halsey et al., 2000; Robroek et al., 2017). Hence, improving our understanding of the spatial and environmental patterns of phototrophic microbial contribution to bryosphere $\mathrm{C}$ uptake across environmental gradients is likely to improve our understanding of biogeochemical cycles in peatlands.

Here, we explore the diversity of phototrophic microbes and their primary productivity in 
covering a broad range of environmental conditions. Specifically, we tested the relationships between phototrophic microbial community composition, structure, and photosynthetic rate in five European Sphagnum-dominated peatlands distributed from southern France to northern Sweden. We hypothesized (i) that phototrophic microbes make a significant contribution to the bryosphere $\mathrm{C}$ uptake, and that (ii) this contribution depends on environmental conditions such as climate (temperature, precipitation) and/or edaphic factors. More specifically, we expected (iii) that environmental conditions strongly influence the taxonomic composition of phototrophic microbial communities, affecting community structure with cascading effects on phototrophic abundance and $\mathrm{C}$ fixation rates. We analysed phototrophic microbial community composition by means of environmental $16 \mathrm{~S}$ and $18 \mathrm{~S}$ rDNA gene sequencing for prokaryotes and eukaryotes, respectively. We further evaluated phototrophic microbial abundance through flux cytometry and microscopy, and we assessed phototrophic microbial $\mathrm{C}$ fixation rates by measuring their photosynthetic efficiency and photosynthetic pigments content.

\section{METHODS}

\subsection{Sites description and sampling}

We collected samples in five European peatlands distributed along a latitudinal gradient ranging from $42^{\circ} \mathrm{N}$ (south of France) to $68^{\circ} \mathrm{N}$ (north of Sweden) in July 2018. From south to north (3000 km as the crow flies), the five peatlands were Counozouls (Lapazeuil) in France $\left(42^{\circ} 41^{\prime} 16 \mathrm{~N}, 2^{\circ} 14^{\prime} 18 \mathrm{E}, 1350 \mathrm{~m}\right.$

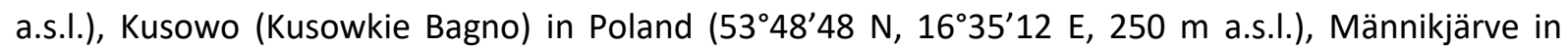
Estonia ( $58^{\circ} 52^{\prime} 30 \mathrm{~N}, 26^{\circ} 15^{\prime} 04 \mathrm{E}, 78 \mathrm{~m}$ a.s.l.), Siikaneva in Finland ( $61^{\circ} 50^{\prime} 00 \mathrm{~N}, 24^{\circ} 11^{\prime} 32 \mathrm{E}, 170 \mathrm{~m}$ a.s.l.) and Abisko (Stordalen) in Sweden (68 $20^{\prime} 54 \mathrm{~N}, 19^{\circ} 04^{\prime} 09 \mathrm{E}, 350 \mathrm{~m}$ a.s.l.) (Fig. 1A). These sites were characterised by flat topographies on a local scale and were associated with different peatland types. Counozouls is a minerotrophic fen, Kusowo and Männikjärve are ombrotrophic bogs, Siikaneva is a boreal oligotrophic fen, and Abisko a palsa mire. The vegetation at all five sites contained a sparse 
vascular plant layer, and was dominated by bryophytes from the Sphagnum genus: S. warnstorfii in Counozouls, S. magellanicum and S. fallax in Kusowo, S. rubellum, S. magellanicum and S. fuscum in Männikjärve, S. papillosum in Siikaneva and S. balticum in Abisko. At each site, we selected five homogeneous plots $(50 \times 50 \mathrm{~cm})$. In each plot we sampled the apical part of Sphagnum mosses $(0-3$ $\mathrm{cm}$ from the capitulum) for analysis of microbial diversity, abundance and biomass as well as photosynthetic rates. We further quantified bryosphere $\mathrm{C}$ fixation rates from the same location (see below).

\subsection{Vegetation, climatic and edaphic parameters}

The vegetation cover (Supplementary Table S1) was assessed in each site and in each plot by taking four pictures of each plot as explained in Sytiuk et al. (2020). The quality and quantity of Sphagnum water-extractable organic matter (Supplementary Table S2) was assessed in each site according to Jassey et al. (2018). Several physico-chemical properties were analysed including pH, dissolved organic carbon and total nitrogen (measured by combustion on a Shimadzu TOC-L), ion concentration (measured on Dionex Ics-5000+ and Dionex DX-120) and dissolved organic matter quality (measured by spectrometry and fluorescence following Hansen et al. (2016). All values were corrected by a blank consisting of demineralized water. Sphagnum shoots were weighted fresh just after sampling. Then they were oven-dried $\left(60^{\circ} \mathrm{C}\right.$ for 48 hours) and weighted after extraction to calculate Sphagnum water content and to express the variables per g of Sphagnum dry weight (g DW). Sphagnum water content was expressed in g of water per g of Sphagnum DW. Finally, long-term bioclimatic variables such as mean annual temperature, annual precipitation and temperature seasonality were retrieved from WorldClim 2.0 (Supplementary Table S3).

(1) 
154

155

156

157

158

159

160

161

162

163

164

165

166

167

168

169

170

171

172

173

174

175

176

177

178

\subsubsection{Microbial DNA extraction}

Three shoots of Sphagnum $(0-3 \mathrm{~cm})$ were sampled with sterile equipment from each plot, cut into small pieces and placed into sterile $5 \mathrm{~mL}$ tubes containing $3 \mathrm{~mL}$ of Lifeguard (Qiagen). For each sample, DNA was extracted using the DNeasy PowerSoil Pro Kit (Qiagen) and following the manufacturer's instructions. A negative extraction (i.e., without Sphagnum) was performed to control for possible contaminations during extraction. For mechanical lysis of the cells, we included two runs of bead beating on a FastPrep FP120 Instrument (MP Biomedicals) for $40 \mathrm{~s}$ at speed $5.0 \mathrm{~m} . \mathrm{s}^{-1}$. DNA was eluted in $70 \mu \mathrm{l}$ of final solution and DNA concentration in each extract was quantified using a Nanodrop ND1000 spectrophotometer. Extracts were stored at $-80^{\circ} \mathrm{C}$ before proceeding with DNA amplification.

\subsubsection{Microbial DNA sequencing}

To investigate prokaryote communities, we amplified a part of the $16 \mathrm{~S}$ rDNA gene, using the primers PCR1_515F and PCR1_928R (Wang \& Qian, 2009). Eukaryote communities were investigated by amplifying a part of the 18S rDNA gene with the primers TAReuk454FWD1 and TAReukREV3 (Tanabe et al., 2016). Both prokaryotic and eukaryotic pairs of primers were tagged with Illumina adapter sequences. PCRs were conducted in a total volume of $50 \mu$ containing $13 \mu$ l of Mastermix AmpliTaq Gold (Thermofisher), $1 \mu$ l of each primer from the chosen pair ( $0.4 \mu \mathrm{M}$ final concentration), $35 \mathrm{ng}$ of DNA (up to $10 \mu \mathrm{l}$ ) and supplemented to $50 \mu \mathrm{l}$ with DNA-free water. The primers' sequences and the PCR programs used are presented in Supplementary Table S4. All PCR products were checked on an agarose gel and samples were then frozen at $-80^{\circ} \mathrm{C}$ until sequencing was performed by the GeT-PlaGe platform (Genotoul, Toulouse, France) with Illumina MiSeq technology and using the V3 chemistry (2×250 bp).

Paired-end fastq sequences (851 910 prokaryotic reads and 891422 eukaryotic reads for 25 samples) were analysed using the FROGS pipeline (Find Rapidly Operational Taxonomic Units Galaxy Solution) on the Galaxy platform (Escudié et al., 2018). Paired-end reads were merged using Vsearch 
179 (10\% of mismatch; Rognes et al., 2016). Sequences were filtered based on their length and primer 180 mismatches were removed, leading to a total of 770602 prokaryotic sequences and 813098 eukaryotic sequences for all samples. Sequences were then de-replicated and clustered into operational taxonomic units (OTUs) using the Swarm clustering method with an aggregation distance of 3 (Mahé et al., 2014). Chimera were identified and removed using Vsearch. Filters were then applied to remove singletons. In total 677947 sequences clustered in 2063 OTUs were kept for prokaryotes, and 718684 sequences clustered in 2050 OTUs were kept for eukaryotes. OTUs were assigned at different taxonomic levels using Blast. We used the Silva 138 database (Quast et al., 2013) for prokaryotic assignation and the $P R^{2}$ v4.12.0 database (Guillou et al., 2013) for eukaryotic assignation.

\subsubsection{Identification of phototrophic OTUs}

Further analyses were done using the Phyloseq R package (McMurdie \& Holmes, 2013). Prokaryotic and micro-eukaryotic sequences were retrieved by removing chloroplast, mitochondria and plant associated sequences. The 25 samples were further rarefied to a total of 50400 prokaryotic sequences clustered into 1172 operational taxonomy units (OTUs), and 21672 micro-eukaryotic sequences clustered in 622 OTUs. Microbial phototrophic OTUs were identified at the genus level, and we outlined the structure of phototrophic microbial communities from the relative abundance of phototrophic OTUs. We considered that an OTU was phototrophic if its affiliated genus was referred as photoautotrophic, photoheterotrophic or mixotrophic in the literature (e.g. (Jia et al., 2015; Kulichevskaya et al., 2014; Li et al., 1999; Okamura et al., 2009; Yurkov et al., 1993)). For instance, we included endosymbiotic mixotrophs (Mitra et al., 2016) among phototrophic OTUs such as the testate amoeba Archerella flavum and Hyalosphenia papilio. Further, OTUs of Chrysophyceae were specifically aligned with the GenBank database using BLAST v. 2.9.0+ as implemented on the NCBI website in order to obtain a precise functional assignation. Indeed, Chrysophyceae have swapped trophic modes several times during their evolutionary history (Graupner et al., 2018). The overwhelming majority of Chrysophyceae OTUs were phototrophic or mixotrophic. 


\subsection{Absolute abundance of phototrophic microbes}

206 To determine the absolute abundance of phototrophs in every site, we sampled five shoots of 207 Sphagnum $(0-3 \mathrm{~cm})$ in each plot, fixed them in $20 \mathrm{ml}$ of glutaraldehyde ( $2 \%$ final concentration), and extracted microorganisms from Sphagnum tissues following the method of Jassey et al. (2011). Then, we quantified the absolute abundance of phototrophic microbes from microbial extracts by means of either flow cytometry or microscope analyses according to microbial body size. cytometry. To do so, we filtrated $300 \mu \mathrm{l}$ aliquots of microbial extract with $40 \mu \mathrm{m}$ Nitex ${ }^{\circledast}$ filters, and placed them in a 96-well microplate. Then, aliquots were run unstained in a Guava ${ }^{\circledR}$ easyCyte ${ }^{\mathrm{TM}} 11 \mathrm{HT}$ cytometer at a flow of $0.59 \mu \mathrm{l} . \mathrm{s}^{-1}$. A maximum of 5000 events were recorded in each sample. Forward and side light scatter (size indication) as well as green fluorescence (presence or absence of possible. We differentiated between strictly phototrophic microbes (microalgae, Cyanobacteria), and chlorophyll) were used to discriminate photosynthetic microorganisms from non-photosynthetic microorganisms (bacteria) (Olson et al., 1989).

Phototrophic microbes with a body size larger than $40 \mu \mathrm{m}$ as well as all Cyanobacteria were identified and counted directly using an inverted microscope. In our samples, Cyanobacteria formed colonies and/or long filaments over $40 \mu \mathrm{m}$ that were not counted by flow cytometry. We double checked that the subsamples filtrated at $40 \mu \mathrm{m}$ did not contain Cyanobacteria under the microscope. Under the microscope, we identified and enumerated phototrophic microbe until species level when mixotrophic microbes (endosymbiotic microbes). Mixotrophic species included testate amoebae (e.g. Archerella flavum, Amphitrema wrightianum, Heleopera sphagni and Hyalosphenia papilio) and ciliates (e.g. Paramecium bursaria and Platyophrya sphagni).

Flow cytometry and inverted microscope abundance data were expressed as the number of individuals per gram of Sphagnum dry weight (DW). We further converted abundance data to C biomass ( $\mu \mathrm{g} C$ per gram of Sphagnum DW) by measuring the biovolume of each species using geometrical shapes under microscope (Gilbert et al., 1998; Mitchell et al., 2003). Biovolumes were 
then converted to $\mathrm{C}$ biomass using conversion factors from the literature (Borsheim \& Bratbak, 1987; Gilbert et al., 1998; Weisse et al., 1990).

\subsection{Microbial photosynthetic rates}

Chlorophyll $a(\mathrm{Chl} a)$ concentrations and the quantum yield of photosystem II ( $\Phi_{\text {PSII }}$ ) were measured in each plot. Chl $a$ concentrations provide an estimate of the amount of photosynthetic machinery, while $\Phi_{\text {PSII }}$ gives the fraction of the absorbed quanta that are used for photosynthetic electron transport and thus provides a measure of photosynthetic efficiency (Wilken et al., 2013). For these analyses, five shoots of Sphagnum $(0-3 \mathrm{~cm})$ were sampled in each plot and immerged in $20 \mathrm{~mL}$ demineralized water. Samples were kept at $4^{\circ} \mathrm{C}$ in the dark and microorganisms were extracted immediately upon return to the laboratory. Samples were shaken at $150 \mathrm{rpm}$ for $1.5 \mathrm{~h}$ and then squeezed to extract microorganisms. The remaining solution was filtered at $100 \mu \mathrm{m}$ with Nitex ${ }^{\circledR}$ filters to remove any Sphagnum residue, while the remaining Sphagnum material was dried at $80^{\circ} \mathrm{C}$ for $48 \mathrm{~h}$ and weighted. Each microbial extract was filtered on a GF/F Whatman ${ }^{\circledR}$ filter $(0.7 \mu \mathrm{m})$ to recover the microbial community.

We measured $\Phi_{\text {PSII }}$ of the microbial community with a Phyto-PAM (Walz, Effeltrich, Germany) after exposing filters to low light for $30 \mathrm{~min}\left(\mathrm{PAR}, 32 \mu \mathrm{mol}\right.$ photons. $\mathrm{m}^{-2} \cdot \mathrm{s}^{-1}$ ). We chose a PAR of $32 \mu \mathrm{mol}$ photons. $\mathrm{m}^{-2} \cdot \mathrm{s}^{-1}$ following light response curve analyses previously ran on test samples (Supplementary Fig. S1). We further quantified the microbial photosynthetic rates in each plot by calculating the photosynthetic electron transport rate (ETR) as described in Wilken et al. (2013), and following Falkowski \& Raven (2013):

(1) ETR $=0.5 \times 1 \times \frac{\text { Chla }}{\text { cell }} \times \Phi_{\text {PSII }} \times a^{*}$ where ETR is the photosynthetic rate, expressed per cell as a measure of the community-weighted mean photosynthetic rate. It was calculated at a light intensity (I) of $32 \mu \mathrm{mol} . \mathrm{m}^{-2} . \mathrm{s}^{-1}$. The calculation of ETR relies on the importance of the microbial photosynthetic machinery (cellular Chla content, $\frac{\text { Chla }}{\text { cell }}$ ) 
and on its photosynthetic efficiency (effective quantum yield of photosystem II, $\Phi_{\text {PSII, measured at a }}$ PAR of $\left.32 \mu \mathrm{mol} \cdot \mathrm{m}^{-2} \cdot \mathrm{s}^{-1}\right)$. Here, a* was the spectrally averaged chlorophyll-specific absorption cross section, for which we took a value of $26.86 \mathrm{~m}^{2} . \mathrm{g} \mathrm{Chla-1}$ as estimated in (Wilken et al., 2013). The ETR was expressed in $\mathrm{mol} \mathrm{e}^{-} \cdot \mathrm{cell}^{-1} \cdot \mathrm{s}^{-1}$.

To obtain Chl $a$ concentrations, the filters used for microbial photosynthetic efficiency and containing microbial communities were frozen at $-80^{\circ} \mathrm{C}$ and freeze-dried in the dark. Adapting the methodology from Capdeville et al. (2019), we soaked lyophilized filters in $1.5 \mathrm{ml}$ of methanol buffered with $2 \% \mathrm{v}$ of ammonium acetate $\left(1 \mathrm{~mol} . \mathrm{I}^{-1}\right)$. Samples were sonicated for $2 \mathrm{~min}$ in an ice bath, then cooled at $-20^{\circ} \mathrm{C}$ in the dark for $15 \mathrm{~min}$ and centrifuged for $5 \mathrm{~min}$ at $10000 \mathrm{rpm}$. The supernatant was recovered (solution 1) while $1 \mathrm{ml}$ of buffered methanol was added to the pellet (solution 2 ). The process was repeated for solution 2 and its supernatant was merged with solution 1 . Then, $1.5 \mathrm{ml}$ of this composite solution was filtered at $0.2 \mu \mathrm{m}$ with a syringe filter and frozen at $-80^{\circ} \mathrm{C}$ before analysis on an HPLC (Barlow et al., 1997). We assessed the concentration of several pigments including Chl $a$, pheophytin $a$ and pheophorbide $a$. As pheophytin $a$ and pheophorbide $a$ are alteration products of $\mathrm{Chl}$ $a$ (Jeffrey et al., 1997), we summed the abundance of these three pigments to have an estimate of overall $\mathrm{Chl} a$ in the samples (hereafter named $\mathrm{Chl} a$ ). $\mathrm{Chl} a$ was expressed in mg per $\mathrm{g}$ of Sphagnum DW and divided by phototroph abundance to have an estimate of cellular Chl $a$ content (expressed in mg.cell $\left.{ }^{-1}\right)$.

\subsection{Microbial C fixation rate and contribution to bryosphere $\mathrm{C}$ fixation rate}

Phototrophic microbial C fixation rates $\left(C_{f i x e d}\right)$ were calculated in each plot from ETR:

(2) $C_{\text {fixed }}=0.25 \times$ ETR $\times$ cell $\times$ Areadw

where we assumed a maximum fixation of $0.25 \mathrm{~mol} \mathrm{CO}_{2}$ per mol of electron (Wilken et al., 2013), and took into account phototrophic microbial abundance (cell) and specific surface of Sphagnum (Area $a_{D W}$ ) 
measured in each plot as the area per gram of Sphagnum DW $(0-3 \mathrm{~cm})$. Carbon fixation rates were expressed in $\mathrm{mg}$ of $\mathrm{CO}_{2}$ fixed per hour and per $\mathrm{m}^{2}$ of Sphagnum.

We measured the bryosphere photosynthetic capacity $\left(\mathrm{A}_{\mathrm{MAX}}\right.$, maximum net $\mathrm{CO}_{2}$ assimilation rate) in each plot from three Sphagnum shoots as described in Jassey \& Signarbieux (2019). The $A_{\operatorname{MAx}}$ was measured with an open-path infrared gas analyser (IRGA) system connected to a $2.5 \mathrm{~cm}^{2}$ PLC-5 chamber (TARGAS-1; PP-Systems) under optimum conditions for light (i.e., $600 \mu \mathrm{mol}$ of photons $\mathrm{m}^{-2} \cdot \mathrm{s}^{-}$ ${ }^{1}$, which was previously determined in the field). Bryosphere $\mathrm{C}$ fixation was expressed in $\mathrm{mg} \mathrm{CO}_{2} \mathrm{~h}^{-1} \cdot \mathrm{m}^{-}$ ${ }^{2}$, allowing comparisons with microbial C fixation rates. To estimate bryosphere $\mathrm{C}$ fixation per $\mathrm{Chl} a$, we also estimated the Chl $a$ content of Sphagnum in each plot. We extracted Chl $a$ from two lyophilized Sphagnum shoots and followed the same extraction method as for phototrophic microbes.

\subsection{Numerical analyses}

Meta-barcoding data were used to explore the diversity and taxonomy of phototrophic microbes, and their community composition. Biostatistics were conducted separately on prokaryotic and eukaryotic microbial communities. Alpha-diversity, non-metric multidimensional scaling (NMDS), and betadiversity metrics based on Bray-Curtis dissimilarity were used to estimate diversity and species turnover between sites. Environmental drivers of phototrophic microbial species turnover were tested using generalized dissimilarity modelling (GDM). The environmental matrix included a selection of variables such as plant community composition (Supplementary Table S1), Sphagnum physicochemical parameters (Supplementary Table S2), and climatic variables (Supplementary Table S3). We selected the most representative and least collinear environmental variables using the package ClustOfVar (12) with an ascendant hierarchical clustering of all available environmental variables. To maximise the stability of partition, nine clusters of variables were retained. In each cluster, the most representative variables were kept for GDM (Supplementary Fig. S2). Variable significance in GDM was determined using matrix permutations and comparing models with each variable permuted and unpermuted. At each step, the least important variables were dropped until all non-significant predictors 
were removed. The GDM was then fit using only significant environmental predictors, and model significance was checked.

All data were tested for normality and transformed if necessary. We tested variation of phototrophic microbial abundance, chlorophyll content, electron transport rate, and C fixation rates between sites (explicative qualitative variable) using analysis of variance (ANOVA). Further, we used linear mixed effects models to test the effects of environmental variables (mean annual temperature, water table depth, annual precipitation; fixed effects) on phototrophic microbial abundance, while accounting for measurements repeated in the same sites (random effect).

The variability of phototrophic $\mathrm{C}$ fixation can be determined by numerous interconnected ecophysiological mechanisms that operate simultaneously at different individual to community scales (Padfield et al., 2018; Yvon-Durocher et al., 2015). One approach to studying such complex interactions is Structural Equation Modelling (SEM; Grace et al. 2014). Following current knowledge on phototrophic eco-physiology (Huete-Ortega et al., 2012; Kalchev et al., 1996; Padfield et al., 2018), we developed an a priori model of hypothesized relationships (Supplementary Fig. S3) within a path diagram allowing a causal interpretation of microbial $\mathrm{C}$ fixation rates in relation to microbial community structure (bacteria and protists), to allometric features (abundance, community-weighted mean body size) and metabolic parameters ( $\mathrm{Chl} a$, photosynthetic rate) (Supplementary Table S5). In this diagram, each path is a component of the model, and represent a linear model between the explanatory and the explained variable. All components of the model were united using the psem function from the piecewiseSEM R package (Lefcheck, 2016). The goodness-of-fit of our a priori SEM model was evaluated using Fisher's statistic and Akaike Information Criterion (AIC). Based on the outputs of the a priori model and by step-wise exclusion and selection of variables, we found the model with the lowest AIC value. The main drivers of microbial C fixation were determined from this final model. We used the first axes of phototrophic prokaryotic and eukaryotic NMDS as indicators of microbial community structure, and electron transport rate (ETR) as indicator of photosynthetic activity. To test to what extent environmental variables affected microbial $\mathrm{C}$ fixation and the 
phototrophic mechanisms underpinning it, we ran our SEM model a second time with microbial variables corrected for the co-varying environmental variables (residual data). To correct microbial variables for environmental conditions, we used the residuals of linear models computed between every microbial variable and the environmental variables identified in the GDM (i.e., precipitation, Sphagnum water content, plant community composition and dissolved organic carbon). All statistical analyses were performed using R version 3.6.2 (R Core Team, 2019).

\section{RESULTS}

\subsection{Diversity and community composition of phototrophic microbes}

The relative abundance of phototrophic microbes varied strongly across sites (Fig. 1A; Supplementary Fig. S4). Phototrophic bacteria represented on average $12 \%$ of the prokaryotic microbial community, and had their largest relative abundance in Counozouls ( $34 \%$ of prokaryotic gene copies) compared to the other sites $\left(<13 \% ; F_{(4,12)}=6.21, P=0.006\right)$. Phototrophic protists constituted a large part of the micro-eukaryotic community, with on average $30 \%$ of micro-eukaryotes gene copies. The relative abundance of phototrophic protists ranged from $53 \%$ in Männikjärve to $17 \%$ in Siikaneva $\left(F_{(4,12)}=9.53\right.$, $P=0.001)$.

Overall, we observed 74 OTUs of phototrophic bacteria and 277 OTUs of phototrophic protists. For phototrophic bacteria, Counozouls had by far the highest OTU richness with on average 30 species per sample $\left(F_{(4,12)}=28.0, P<0.001\right.$; Fig. 2B), whilst Siikaneva had the lowest richness (10 species per sample on average). Despite significant variation in OTU richness, we found that phototrophic bacteria diversity (Shannon's entropy) was stable across sites $\left(F_{(4,12)}=0.9, P=0.48\right.$, Fig. 2B). For phototrophic protists, we found the highest OTU richness in Männikjärve (52 species) $\left(F_{(4,12)}=3.2, P=0.05\right.$; Fig. 2B) and the lowest in Abisko (31 species). Phototrophic protist diversity followed the latitudinal gradient with a slight but significant decrease from Counozouls to Abisko $\left(F_{(4,12)}=4.6, P=0.02\right.$; Fig. 2B). 
358 (Supplementary Fig. S5). Proteobacteria and Cyanobacteria dominated phototrophic bacteria across 359 sites. Proteobacteria $\left(F_{(4,12)}=113.24, P<0.001\right)$ were relatively more abundant in Kusowo, Männikjärve and Siikaneva (>80 \%), while Cyanobacteria $\left(F_{(4,12)}=10.4, P<0.001\right)$ relatively dominated in Counozouls (60.8\%) and Abisko (68.5\%) (Fig. 2A). Gemmatimonadetes and Chloroflexi were only present in Counozouls (Fig. 2A). Proteobacteria were primarily represented by the orders Acetobacterales and Rhizobiales, whereas Cyanobacteria were mostly represented by Nostocales relative abundance), Ochrophyta $(15.3 \%)$ and Streptophyta $(7.4 \%)$ were the three most relatively abundant phyla (Fig. 2A, Supplementary Fig. S5). At the class level, Chlorophyta were mainly represented by Trebouxiophyceae and Chlorophyceae; Ochrophyta by Chrysophyceae; and Streptophyta by Zygnemophyceae and Klebsormidiophyceae. The relative abundance of the different classes varied significantly along the latitudinal gradient (Fig. 2A, Supplementary Fig. S5). Both phototrophic bacteria and protist assemblages clustered at the site level (NMDS with Bray-Curtis dissimilarity; Fig. 1B and Fig. 1C). Pairwise comparisons of beta-diversity based on BrayCurtis dissimilarity showed substantial species turnover between sites (Supplementary Table S6). More than half of all phototrophic microbial OTUs identified were indeed found in only one site (Supplementary Fig. S6) and only 13 OTUs (6 affiliated to bacteria and 7 to protists) were found in all sites. Furthermore, we found that both phototrophic bacteria and protist turnover (i.e., pairwise community compositional dissimilarity) increased with environmental distance among sites (i.e., pairwise environmental dissimilarity; Fig. 3A, 3C). Phototrophic microbial communities of both domains were increasingly dissimilar as shrubs replaced herbaceous plants in the vegetation (Fig. 3B, 3D). Phototrophic bacteria turnover was also driven by an increase in precipitation and dissolved organic carbon (Fig. 3B), while the turnover of phototrophic protists was strongly driven by changes in Sphagnum water content (Fig. 3D). 


\subsection{Absolute abundance, biomass and size structure of phototrophs}

385

The absolute abundance of phototrophic microbes strongly decreased along the latitudinal gradient

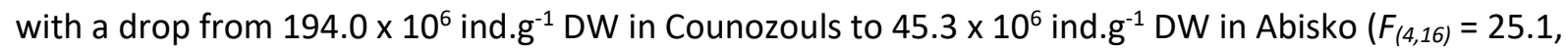
$P<0.001 ;$ Fig. 4A). This pattern was mostly driven by phototrophic microbes with a body size $<40 \mu \mathrm{m}$ that constituted the majority of microbial phototrophs (98.5\%, Supplementary Fig. S7). Large phototrophic microbes and large mixotrophs (body size $>40 \mu \mathrm{m}$ ) were less abundant and showed opposite patterns with an increase of their absolute abundance toward high latitudes $\left(F_{(4,16)}=11.8, P\right.$ $<0.001$ and $F_{(4,16)}=20.3, P<0.001$ respectively, Supplementary Fig. S7, Fig. 4B). Consequently, the community-weighted mean body size per cell increased toward high latitudes $\left(F_{(4,16)}=20.3, P<0.001\right)$, with phototrophic microbes being on average 28 times larger in Abisko than in Counozouls (Fig. 4C). On the whole, the total biomass of the phototrophic community tended to increase toward high latitudes, from $1049 \mu \mathrm{gC} . \mathrm{g}^{-1} \mathrm{DW}$ in Counozouls to $1634 \mu \mathrm{gC} . \mathrm{g}^{-1} \mathrm{DW}$ in Abisko $\left(F_{(4,16)}=46.3, P<0.001\right.$; Fig. 4D). Within the phototrophic community, Cyanobacteria had a higher absolute abundance in Counozouls and in Abisko $\left(1.04 \times 10^{6} \pm 0.01\right.$ ind. $\left.\mathrm{g}^{-1} \mathrm{DW}\right)$ than in the other sites $\left(0.20 \times 10^{6} \pm 0.04\right.$ ind.g${ }^{1}$ DW) $\left(F_{(4,16)}=20.3, P<0.001\right.$; Supplementary Fig. S8). However, considering biomasses, the ratio Cyanobacteria to phototrophic microbes was higher in Counozouls and Kusowo $(0.61 \pm 0.17)$ compared to the other sites $(0.13 \pm 0.03)\left(F_{(4,16)}=16.9, P<0.001\right.$; Supplementary Fig. S8).

Phototrophic microbial abundance correlated positively with annual precipitation $(r=0.75$, $\left.F_{(1,23)}=29.4, P<0.001\right)$, and to a lesser extent with plant composition $\left(r=0.55, F_{(1,23)}=10.29, P=0.004\right)$, phototrophic microbes being more abundant when shrubs were absent. The abundance of large phototrophic microbes was negatively correlated with the water table depth $\left(r=-0.80, F_{(1,23)}=15.05\right.$, $P<0.001)$, meaning that large phototrophic microbes were more abundant when water was close to the surface. The abundance of large mixotrophs correlated negatively with both annual precipitation $\left(r=-0.87, F_{(1,23)}=73.83, P<0.001\right)$ and mean annual temperature $\left(r=-0.83, F_{(1,23)}=51.10, P<0.001\right)$. 


\subsection{Photosynthetic rates and C fixation of phototrophic microbial communities}

411 The chlorophyll content of phototrophic microbes increased along the gradient $(+400 \%$ between Counozouls and Abisko; $\left.F_{(4,16)}=5.78, P=0.005 ; \mathrm{Fig} .4 \mathrm{E}\right)$. Similar patterns were found for photosynthetic rates $\left(+380 \% ; F_{(4,16)}=3.7, P=0.02 ; \mathrm{Fig} .4 \mathrm{~F}\right)$. On average, phototrophic microbes fixed $8.8(3.8-16.2)$ $\mathrm{mg} \mathrm{CO} 2 \cdot \mathrm{h}^{-1} \cdot \mathrm{m}^{-2}$ over the gradient. Phototrophic microbial C fixation varied between sites, from $16.2 \mathrm{mg}$

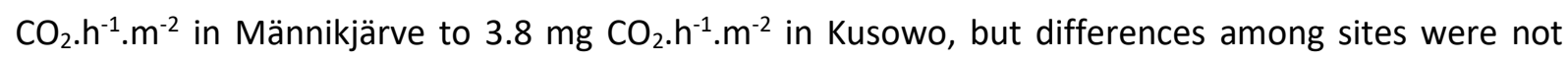
significant $\left(F_{(4,12)}=1.10, P=0.39 ;\right.$ Fig. $\left.5 \mathrm{~A}\right)$. of phototrophic abundance (path $=0.42$ ) and metabolism (photosynthetic rate, path $=0.70$ ) (Fig. 6). Indirectly, microbial C fixation was mediated by the community structure of phototrophic bacteria and protists, which influenced phototrophic allometry. In particular, community structure influenced the microbial abundance (path $=1.09$ and path $=-0.43$ for bacteria and protist community structure, respectively) and the community-weighted mean body size (path $=-0.46$ and path $=0.70$ for bacteria and protist community structure, respectively), which had cascading effects on phototrophs metabolism (chlorophyll content per individual, and finally photosynthetic rate). A comparison with the SEM model corrected from environmental variables did not reveal strong alterations of the pathways (Supplementary Fig. S9). This indicated that the phototrophic mechanisms identified in our SEM model were independent from environmental changes. pattern with higher $\mathrm{C}$ uptake in the three northern sites compared to the two southern sites $\left(F_{(4,12)}=6.70, P=0.002 ; \mathrm{Fig} .5 \mathrm{~A}\right)$. The bryosphere fixed on average $111.5 \mathrm{mg} \mathrm{CO} 2 \cdot \mathrm{h}^{-1} \cdot \mathrm{m}^{-2}$. The microbial the bryosphere for a given amount of $\mathrm{Chl} a\left(F_{(1,48)}=79.15, P<0.001\right.$; Fig. 5B). We further estimated 
sites (Fig. 5C). This contribution ranged on average from $4.1 \%$ in Siikaneva to $12.4 \%$ in Abisko (Fig. 5C), but differences among sites were not significant $\left(F_{(4,12)}=1.44, P=0.27\right)$.

\section{DISCUSSION}

Microbial communities play an important role in maintaining multiple ecosystem functions that are important for $\mathrm{C}$ cycling. Whilst methanogens, fungi and other bacteria are known for their key role in C mineralization and respiration (e.g., (Galand et al., 2005; Myers et al., 2012; Thormann, 2006)), we show that, across a wide range of climatic conditions, phototrophic microbial communities are important for peatland $\mathrm{C}$ dynamics through their contribution to $\mathrm{C}$ uptake. Our study revealed that phototrophic microbes were phylogenetically diverse and highly abundant in peatlands throughout the latitudinal gradient. The structure and abundance of phototrophic microbial communities varied along the latitudinal gradient, driven by shifts in biotic and abiotic environmental factors (e.g., climate, plant composition). Despite microbial species turnover, our findings demonstrated a constant microbial $\mathrm{CO}_{2}$ fixation along the gradient. Our results therefore provide the first in situ evidence for the role of phototrophic microbes in peatland $\mathrm{C}$ uptake at a continental scale.

\subsection{Phototrophy is a dominant microbial process in surface peat}

On average, we found $7.5 \times 10^{7}$ microbial phototrophic cells per gram of dry moss in the top $3 \mathrm{~cm}$ of the Sphagnum carpet. This number is in line with previous studies, where phototrophic microbial abundance typically ranged between $10^{6}$ and $10^{8}$ cells per gram of dry moss (Basińska et al., 2020; Jassey et al., 2015). We found that phototrophic microbes represented an approximate biomass of 1.0 mg C per gram of dry moss. This is, by comparison, higher than the heterotrophic bacterial biomass (approximately $0.5 \mathrm{mg} \mathrm{C}$ per g DW), or the biomass of heterotrophic protists (approximately $0.15 \mathrm{mg}$ C per g DW) found in peatlands at the same depth (Jassey et al., 2011, 2015; Mitchell et al., 2003). Phototrophic microbes constitute therefore the most important component of microbial $\mathrm{C}$ biomass in 
the apical part of the Sphagnum carpet, which suggests that phototrophy is a dominant microbial process in the upper peatland layer.

In terms of community composition, we found that, on average, $12 \%$ of prokaryotic sequences and $30 \%$ of micro-eukaryotic sequences belonged to phototrophic microbial lineages. These relative proportions were unexpectedly high, especially compared to previous meta-barcoding studies where phototrophic microbes represented less than 1\% of prokaryotes (Bragina et al., 2012, 2014) and only 10\% of micro-eukaryotes (Geisen et al., 2015; Heger et al., 2018). These high relative abundances of phototrophic microbes most probably result from our experimental design. We indeed sampled the top $3 \mathrm{~cm}$ of the Sphagnum carpet, where light conditions are favourable for phototrophic microbial abundance and activity (Jassey et al., 2013; Reczuga et al., 2020; Robroek et al., 2009).

Our results further revealed that both communities of phototrophic bacteria and protists were relatively more abundant in peatlands than in other terrestrial ecosystems (Cano-Díaz et al., 2019; Oliverio et al., 2020). This alters our perception of the global distribution of soil phototrophic microbes, as until now, drylands were considered as the main phototrophic microbial hotspots (Bates et al., 2013; Oliverio et al., 2020). These findings therefore highlight the potential importance of peatland phototrophic microbes for the global C cycle.

\subsection{Peatland phototrophic communities are diverse and environment-specific}

We identified 351 phototrophic microbial OTUs over the gradient, belonging to diverse prokaryotic and eukaryotic taxonomic clades. While phototrophic communities were relatively dominated by Chlorophyta (micro-eukaryote) and Alphaproteobacteria (prokaryotes), we nevertheless identified seven phyla of phototrophic micro-eukaryote, and four out of the seven existing phyla of phototrophic prokaryotes (Zeng et al., 2014). In link with this high taxonomic diversity, we identified a wide range of photosynthetic pathways. Within micro-eukaryotes, we found strict phototrophic organisms (e.g., phototrophic Ochrophyta, Chlorophyta) and mixotrophic organisms (e.g., endosymbiotic Ciliophora, Lobosa). Within prokaryotes, the OTUs identified formed a continuum between photoautotrophy and 
photoheterotrophy (Kulichevskaya et al., 2014; Yurkov et al., 1993), with uncertainty about the levels of autotrophy. For instance, Cyanobacteria can acquire organic $C$ and downregulate their photosynthesis when in symbiosis with other plants (Black \& Osborne, 2004), while some phototrophic Proteobacteria can grow both photoautotrophically and photoheterotrophically (Tang et al., 2011). Even though the occurrence of Cyanobacteria and phototrophic Proteobacteria is generally accepted in peatlands, they remain poorly explored and this calls for a deeper consideration of their role in peatland C cycling.

Beyond the high taxonomic diversity, our results revealed that phototrophic microbial communities were site-specific due to a high species turnover across sites. Species turnover was largely driven by water availability (precipitation and Sphagnum water content), plant cover and dissolved organic C. This indicates that complex interactions among climate, Sphagnum properties and vegetation determine the community structure of phototrophic microbes in peatlands. For instance, by reducing light availability at the Sphagnum surface, vascular plant cover could structure phototrophic microbial communities as shown in other terrestrial systems such as grasslands or alpine deserts (Davies et al., 2013; Řeháková et al., 2017). Moreover, this close link between phototrophic microbial and plant communities suggests that plants affect phototrophic microbes through the nutrients and numerous allelochemical compounds they release in their surrounding environment, by favouring or inhibiting specific taxa (Asao \& Madigan, 2010; Hamard et al., 2019; Řeháková et al., 2017; Stoler \& Relyea, 2011; Sytiuk et al., 2021).

\subsection{The microbial C fixation depends on the community structure of phototrophic microbes}

Our structural equation modelling revealed the links by which species turnover affected microbial C fixation rates. We identified two indirect pathways: first, microbial community structure influenced C fixation rates through an alteration of microbial abundance; and second, through an alteration of community-weighted mean body size and individual-level photosynthetic rates. Both pathways were antagonists: when the phototrophic community structure shifted and induced an increase of the 
microbial abundance, it also led to a decrease of the community-weighted mean body size and a decrease of the individual-level photosynthetic rates. This compensation resulted in constant $\mathrm{C}$ fixation rates across the gradient. This result is in line with previous studies where isometric laws between body size, metabolic rates and abundance of phytoplankton have been found (Cermeño et al., 2006; Huete-Ortega et al., 2012). Altogether, these findings suggest that the total energy processed by phototrophic microbes in peatlands for $\mathrm{C}$ fixation was constant across our large latitudinal gradient. The influence of microbial community structure on $\mathrm{C}$ fixation rates could be related to specific mechanisms on the two identified pathways. For instance, the presence of certain species, such as colonial phototrophic microbes, could increase the abundance of phototrophic microbes (Finkel et al., 2010). Some colonial phototrophic species (e.g. Anabanena sp.) can indeed form long filaments composed by numerous cells (Gilbert \& Mitchell, 2006). These filaments are hardly eaten by grazers (DeColibus et al., 2017), thus favouring phototrophic abundance. In addition, the community-weighed mean body size, and hence, the size of the photosynthetic apparatus at the individual level (Finkel et al., 2010; Kalchev et al., 1996), depends on the phototrophic species present in the community. Therefore, communities composed of larger phototrophic microbes had higher individual-level photosynthetic rates, as was the case in the northern sites, where large mixotrophic species were present. This result suggests that mixotrophic species are key organisms by their size, driving microbial photosynthesis rates and $\mathrm{C}$ uptake in peatlands. This is in line with previous studies on the contribution of mixotrophic testate amoebae to bryosphere C fixation (Jassey et al., 2015). It also echoes observations in oceanic environments where mixotrophic plankton plays a paramount role in ecosystem primary productivity (Ward \& Follows, 2016; Worden et al., 2015).

\subsection{Implications of microbial C fixation for peatland C dynamics}

Phototrophic microbes fixed on average $8.8(3.8-16.2) \mathrm{mg} \mathrm{CO}_{2} \mathrm{~h}^{-1} \mathrm{~m}^{-2}$ across sites, which represented on average $9 \%(4 \%-12 \%)$ of the total bryosphere C fixation. This contribution might seem relatively

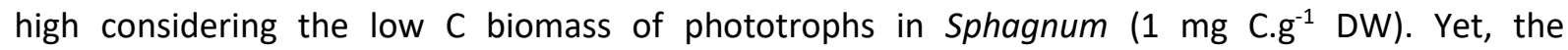


photosynthetic rate per chlorophyll content of phototrophs is four to ten times higher than for

539 Sphagnum. It explains why phototrophic microbes contribute significantly to the bryosphere C fixation 540 despite their small size and biomass. It further indicates that the small fraction of $C$ found in phototrophic biomass does not reflect the amount of $C$ they fix. This result is in line with a previous study suggesting that Cyanobacteria and green algae can display a 50-fold higher efficiency in $\mathrm{CO}_{2}$ fixation compared to plants due to their faster growth rate (Rossi et al., 2015). phototrophic microbes play an important- and until now overlooked- role in peatland C cycling. Assuming that our data are representative for northern peatlands, we roughly estimated that phototrophic microbes would fix a global amount of $c a .75$ MT C per year in northern peatlands (Supplementary Methods, Supplementary Table S7). By comparison, this amount is about the same magnitude as C loss from northern peatlands in response to climate warming (Dorrepaal et al., 2009). We note that our estimates of microbial contribution to annual peatland $C$ uptake are based on several assumptions that might lead to uncertainty. For example, seasonal climatic variation in microbial phototrophic activity could influence the values that we present here. In particular, water availability and Sphagnum water content vary over the year, and thus shape the community structure and C fixation rates of phototrophic microbes accordingly. Yet, pototrophic microbial communities respond fast to water availability changes in peatlands (less than two weeks, Reczuga et al., 2018). We thus believe that our estimations are representative of the summer conditions at the time we sampled. Moreover, phototrophic microbial abundance have been shown to peak in spring and autumn (Reczuga et al., 2020), when their abundance can double (Rober et al., 2014). This suggests that the annual C fixation by microbial phototrophs might therefore be higher than expected. We also acknowledge that our fluorescence-based measurements of microbial photosynthesis could introduce some bias in our estimates. In particular, the high proportion of Cyanobacteria in some sites could lead to an underestimation of photosynthetic rates, as chlorophyll fluorescence measurements are often underestimated in Cyanobacteria due to their prokaryotic nature (Ogawa et al., 2017; Schuurmans et 
al., 2015). We however did not observed this effect in our samples (Supplementary Fig. S10). Similarly, measurements of chlorophyll fluorescence do not take into account the photosynthesis performed by the bacteriochlorophyll of phototrophic prokaryotes. However, microbial C fixation rates estimated using fluorescence were of the same magnitude as $C$ fixation rates quantified using a gas analyser (Supplementary Fig. S11). Finally, we caution that the estimate of peatland surface used for upscaling (Leifeld \& Menichetti, 2018) is not restricted to Sphagnum-dominated peatlands and includes rich fens. However, Sphagnum-dominated peatlands (ombrotrophic bogs and poor fens) represent a high proportion of total peatlands, accounting for instance for more than $65 \%$ in North America (Hugelius et al., 2020). Further, phototrophic microbial C fixation in rich fens has been found of either similar or higher magnitude than our estimates (Wyatt et al., 2012). Despite these limitations, our findings clearly underline the importance of phototrophic microbes for peatland C cycle through the large amount of C they fix.

\subsection{Conclusions and perspectives}

The current consensus on C pathways in terrestrial ecosystems is that plants are the only or at least the main route for soil C uptake (Krumins et al., 2013; Liang et al., 2017). Our study questions this assumption and shows that phototrophic microbial photosynthesis could represent about $10 \%$ of peatland primary productivity, demonstrating that phototrophic microbes cannot be ignored in peatland $C$ dynamics. Their role remains nevertheless obscure in terms of $C$ sequestration, as the fate of microbial-fixed $\mathrm{C}$ in peatlands is currently unknown. The only study to date suggests that microbial fixed $\mathrm{C}$ would not promote peatland $\mathrm{C}$ accumulation. This study shows that phototrophic microbes in a fen ecosystem release 20 to $40 \%$ of the C they fix as exudates (Wyatt \& Turetsky, 2015), contributing to DOC concentrations and promoting heterotrophic respiration (Wyatt et al., 2014; Wyatt \& Turetsky, 2015). The fate of the remaining $C$ fixed (60 to $80 \%$ ) is however unknown. If less labile than exudates, this $C$ could contribute to peat formation. We show here that our current understanding of peatland $\mathrm{C}$ dynamics is missing a large piece of the jigsaw puzzle, highlighting the urgent need to further explore 
phototrophic microbes. Including microbial C uptake in biogeochemical peatland C models would certainly improve predictions of the peatland $\mathrm{C}$ balance under future global changes. Particular attention should be given to seasonal variation across phototrophic microbial communities, and to the fate of the $C$ they fix. The incorporation of these aspects in future ecological models to refine our understanding of peatland $\mathrm{C}$ biogeochemical cycles is a worthy challenge.

\section{ACKNOWLEDGMENTS}

This work was supported by the MIXOPEAT project (Grant No. ANR-17-CE01-0007 to VEJJ) funded by the French National Research Agency. EL was funded by an "Atracción de Talento Investigador" (2017130 T1/AMB-5210) grant from the Consejería de Educación, Juventud y Deporte Comunidad de Madrid (Spain). PK acknowledges funding from the Swedish Research Council Formas. Tallinn University Research Fund and the project "Life Peat Restore" supported MK. We gladly acknowledge the support from the Genome \& Transcriptome platform of Genopole Toulouse (Genotoul) where environmental DNA sequencing was performed, and from the Bioinformatics platform of Genotoul from which we used computing clusters to perform DNA bioinformatic analyses. We thank the Plateforme Analyses Physico-Chimiques from the Laboratoire Ecologie Fonctionnelle et Environnement (Toulouse) for their analyses (water extractable organic matter) and for the provision of an HPLC (pigments quantification). We also thank Bruno Leroux from the Fédération Aude Claire and the Syndicat Forestier de Counozouls for giving the access to the site of Counozouls.

\section{CONFLICT OF INTEREST}

The authors declare that the research was conducted in the absence of any commercial or financial relationships that could be construed as a potential conflict of interest. 
616

VEJJ conceived the ideas and designed methodology with the help of SH. VEJJ choose the sites with the help of ML, MK, EST, GIR and ED. VEJJ and SH collected the data with the help of MK. SH and VEJJ proceeded to laboratory work with the help of $\mathrm{MB}, \mathrm{AS}, \mathrm{JL}$ and EL. SH analysed the data with the help of VEJJ, EL, MB and AS. SH and VEJJ led the writing of the manuscript with the help of RC and PK. All authors contributed critically to the drafts and gave final approval for publication.

\section{DATA AVAILABILITY}

Data are available from Figshare (10.6084/m9.figshare.c.5190902).

\section{REFERENCES}

Asao, M., \& Madigan, M. T. (2010). Taxonomy, phylogeny, and ecology of the heliobacteria. Photosynthesis Research, 104(2-3), 103-111. https://doi.org/10.1007/s11120-009-9516-1

Barlow, R. G., Cummings, D. G., \& Gibb, S. W. (1997). Improved resolution of mono- and divinyl chlorophylls $\mathrm{a}$ and $\mathrm{b}$ and zeaxanthin and lutein in phytoplankton extracts using reverse phase C-8 HPLC. Marine Ecology Progress Series, 161, 303-307. https://doi.org/10.3354/meps161303

Bar-On, Y. M., Phillips, R., \& Milo, R. (2018). The biomass distribution on Earth. Proceedings of the National Academy of Sciences, 115(25), 6506-6511. https://doi.org/10.1073/pnas.1711842115

Basińska, A. M., Reczuga, M. K., Gąbka, M., Stróżecki, M., Łuców, D., Samson, M., Urbaniak, M., Leśny, J., Chojnicki, B. H., Gilbert, D., Sobczyński, T., Olejnik, J., Silvennoinen, H., Juszczak, R., \& Lamentowicz, M. (2020). Experimental warming and precipitation reduction affect the 
biomass of microbial communities in a Sphagnum peatland. Ecological Indicators, 112, 106059. https://doi.org/10.1016/j.ecolind.2019.106059

Bates, S. T., Clemente, J. C., Flores, G. E., Walters, W. A., Parfrey, L. W., Knight, R., \& Fierer, N. (2013). Global biogeography of highly diverse protistan communities in soil. The ISME Journal, 7(3), 652-659. https://doi.org/10.1038/ismej.2012.147

Behrenfeld, M. J. (2014). Climate-mediated dance of the plankton. Nature Climate Change, 4(10), 880-887. https://doi.org/10.1038/nclimate2349

Black, K., \& Osborne, B. (2004). An assessment of photosynthetic downregulation in cyanobacteria from the Gunnera-Nostoc symbiosis. New Phytologist, 162(1), 125-132. https://doi.org/10.1111/j.1469-8137.2004.01008.x

Borsheim, K. Y., \& Bratbak, G. (1987). Cell volume to cell carbon conversion factors for a bacterivorous Monas sp. enriched from seawater. Marine Ecology Progress Series, 36, 171175.

Bragina, A., Berg, C., Cardinale, M., Shcherbakov, A., Chebotar, V., \& Berg, G. (2012). Sphagnum mosses harbour highly specific bacterial diversity during their whole lifecycle. The ISME Journal, 6(4), 802-813. https://doi.org/10.1038/ismej.2011.151

Bragina, A., Oberauner-Wappis, L., Zachow, C., Halwachs, B., Thallinger, G. G., Müller, H., \& Berg, G. (2014). The Sphagnum microbiome supports bog ecosystem functioning under extreme conditions. Molecular Ecology, 23(18), 4498-4510. https://doi.org/10.1111/mec.12885

Bridgham, S. D., Megonigal, J. P., Keller, J. K., Bliss, N. B., \& Trettin, C. (2006). The carbon balance of North American wetlands. Wetlands, 26(4), 889-916. https://doi.org/10.1672/02775212(2006)26[889:TCBONA]2.0.CO;2

Cano-Díaz, C., Maestre, F. T., Eldridge, D. J., Singh, B. K., Bardgett, R. D., Fierer, N., \& DelgadoBaquerizo, M. (2019). Ecological niche differentiation in soil cyanobacterial communities across the globe. BioRxiv, 531145. https://doi.org/10.1101/531145 
Capdeville, C., Pommier, T., Gervaix, J., Fromard, F., Rols, J.-L., \& Leflaive, J. (2019). Mangrove Facies Drives Resistance and Resilience of Sediment Microbes Exposed to Anthropic Disturbance. Frontiers in Microbiology, 9. https://doi.org/10.3389/fmicb.2018.03337

Caron, D. A., Alexander, H., Allen, A. E., Archibald, J. M., Armbrust, E. V., Bachy, C., Bell, C. J., Bharti, A., Dyhrman, S. T., Guida, S. M., Heidelberg, K. B., Kaye, J. Z., Metzner, J., Smith, S. R., \& Worden, A. Z. (2017). Probing the evolution, ecology and physiology of marine protists using transcriptomics. Nature Reviews Microbiology, 15(1), 6-20. https://doi.org/10.1038/nrmicro.2016.160

Cermeño, P., Marañón, E., Harbour, D., \& Harris, R. P. (2006). Invariant scaling of phytoplankton abundance and cell size in contrasting marine environments. Ecology Letters, 9(11), 12101215. https://doi.org/10.1111/j.1461-0248.2006.00973.x

Chavent, M., Kuentz, V., Liquet, B., \& Saracco, J. (2011). Classification de variables : le package ClustOfVar. 43èmes Journées de Statistique (SFdS), 6 p. https://hal.archives-ouvertes.fr/hal00601919

Ciais, P., Sabine, C., Govindasamy, B., Bopp, L., Brokvin, V., Canadell, J. G., Chhabra, A., DeFries, R., Galloway, J., Heimann, M., Jones, C., Le Quéré, C., Myneni, R., Piao, S., \& Thornton, P. (2013). Chapter 6: Carbon and Other Biogeochemical Cycles. In Climate Change 2013: The Physical Science Basis (Cambridge University Press). Stocker, T., Qin, D., and Platner, G.-K.

Davies, L. O., Schäfer, H., Marshall, S., Bramke, I., Oliver, R. G., \& Bending, G. D. (2013). Light Structures Phototroph, Bacterial and Fungal Communities at the Soil Surface. PLOS ONE, 8(7), e69048. https://doi.org/10.1371/journal.pone.0069048

Delgado-Baquerizo, M., Oliverio, A. M., Brewer, T. E., Benavent-González, A., Eldridge, D. J., Bardgett, R. D., Maestre, F. T., Singh, B. K., \& Fierer, N. (2018). A global atlas of the dominant bacteria found in soil. Science, 359(6373), 320-325. https://doi.org/10.1126/science.aap9516 
Dorrepaal, E., Toet, S., van Logtestijn, R. S. P., Swart, E., van de Weg, M. J., Callaghan, T. V., \& Aerts, R. (2009). Carbon respiration from subsurface peat accelerated by climate warming in the subarctic. Nature, 460(7255), 616-619. https://doi.org/10.1038/nature08216

Elbert, W., Weber, B., Burrows, S., Steinkamp, J., Büdel, B., Andreae, M. O., \& Pöschl, U. (2012). Contribution of cryptogamic covers to the global cycles of carbon and nitrogen. Nature Geoscience, 5(7), 459-462. https://doi.org/10.1038/ngeo1486

Escudié, F., Auer, L., Bernard, M., Mariadassou, M., Cauquil, L., Vidal, K., Maman, S., HernandezRaquet, G., Combes, S., \& Pascal, G. (2018). FROGS: Find, Rapidly, OTUs with Galaxy Solution. Bioinformatics, 34(8), 1287-1294. https://doi.org/10.1093/bioinformatics/btx791

Falkowski, P. G., \& Raven, J. A. (2013). Aquatic Photosynthesis: Second Edition. Princeton University Press.

Fierer, N. (2017). Embracing the unknown: disentangling the complexities of the soil microbiome. Nature Reviews Microbiology, 15(10), 579-590. https://doi.org/10.1038/nrmicro.2017.87

Finkel, Z. V., Beardall, J., Flynn, K. J., Quigg, A., Rees, T. A. V., \& Raven, J. A. (2010). Phytoplankton in a changing world: cell size and elemental stoichiometry. Journal of Plankton Research, 32(1), 119-137. https://doi.org/10.1093/plankt/fbp098

Galand, P. E., Fritze, H., Conrad, R., \& Yrjälä, K. (2005). Pathways for Methanogenesis and Diversity of Methanogenic Archaea in Three Boreal Peatland Ecosystems. Applied and Environmental Microbiology, 71(4), 2195-2198. https://doi.org/10.1128/AEM.71.4.2195-2198.2005

Geisen, S., Mitchell, E. A. D., Adl, S., Bonkowski, M., Dunthorn, M., Ekelund, F., Fernández, L. D., Jousset, A., Krashevska, V., Singer, D., Spiegel, F. W., Walochnik, J., \& Lara, E. (2018). Soil protists: a fertile frontier in soil biology research. FEMS Microbiology Reviews, 42(3), 293323. https://doi.org/10.1093/femsre/fuy006

Geisen, S., Tveit, A. T., Clark, I. M., Richter, A., Svenning, M. M., Bonkowski, M., \& Urich, T. (2015). Metatranscriptomic census of active protists in soils. The ISME Journal, 9(10), 2178-2190. https://doi.org/10.1038/ismej.2015.30 
Gilbert, D., Amblard, C., Bourdier, G., \& Francez, A.-J. (1998). The Microbial Loop at the Surface of a Peatland:Structure, Function, and Impact of Nutrient Input. Microbial Ecology, 35(1), 83-93. https://doi.org/10.1007/s002489900062

Gilbert, D., \& Mitchell, E. A. D. (2006). Chapter 13 Microbial diversity in Sphagnum peatlands. In I. P. Martini, A. Martínez Cortizas, \& W. Chesworth (Eds.), Developments in Earth Surface Processes (Vol. 9, pp. 287-318). Elsevier. https://doi.org/10.1016/S0928-2025(06)09013-4

Goldsborough, L., \& Robinson, G. (1996). Patterns in wetlands. In Algal ecology: freshwater benthic ecosystems (Academic). Stevenson RJ, Bothwell ML, Lowe RL.

Graupner, N., Jensen, M., Bock, C., Marks, S., Rahmann, S., Beisser, D., \& Boenigk, J. (2018). Evolution of heterotrophy in chrysophytes as reflected by comparative transcriptomics. FEMS Microbiology Ecology, 94(4). https://doi.org/10.1093/femsec/fiy039

Guillou, L., Bachar, D., Audic, S., Bass, D., Berney, C., Bittner, L., Boutte, C., Burgaud, G., de Vargas, C., Decelle, J., del Campo, J., Dolan, J. R., Dunthorn, M., Edvardsen, B., Holzmann, M., Kooistra, W. H. C. F., Lara, E., Le Bescot, N., Logares, R., ... Christen, R. (2013). The Protist Ribosomal Reference database (PR2): a catalog of unicellular eukaryote Small Sub-Unit rRNA sequences with curated taxonomy. Nucleic Acids Research, 41(D1), D597-D604. https://doi.org/10.1093/nar/gks1160

Halsey, L. A., Vitt, D. H., \& Gignac, L. D. (2000). Sphagnum-Dominated Peatlands in North America since the Last Glacial Maximum: Their Occurrence and Extent. The Bryologist, 103(2), 334352. JSTOR.

Hamard, S., Robroek, B. J. M., Allard, P.-M., Signarbieux, C., Zhou, S., Saesong, T., de Baaker, F., Buttler, A., Chiapusio, G., Wolfender, J.-L., Bragazza, L., \& Jassey, V. E. J. (2019). Effects of Sphagnum Leachate on Competitive Sphagnum Microbiome Depend on Species and Time. Frontiers in Microbiology, 10. https://doi.org/10.3389/fmicb.2019.02042

Hansen, A. M., Kraus, T. E. C., Pellerin, B. A., Fleck, J. A., Downing, B. D., \& Bergamaschi, B. A. (2016). Optical properties of dissolved organic matter (DOM): Effects of biological and photolytic 
degradation. Limnology and Oceanography, 61(3), 1015-1032.

https://doi.org/10.1002/Ino.10270

Heger, T. J., Giesbrecht, I. J. W., Gustavsen, J., Campo, J. del, Kellogg, C. T. E., Hoffman, K. M., Lertzman, K., Mohn, W. W., \& Keeling, P. J. (2018). High-throughput environmental sequencing reveals high diversity of litter and moss associated protist communities along a gradient of drainage and tree productivity. Environmental Microbiology, 20(3), 1185-1203. https://doi.org/10.1111/1462-2920.14061

Huete-Ortega, M., Cermeño, P., Calvo-Díaz, A., \& Marañón, E. (2012). Isometric size-scaling of metabolic rate and the size abundance distribution of phytoplankton. Proceedings of the Royal Society B: Biological Sciences, 279(1734), 1815-1823. https://doi.org/10.1098/rspb.2011.2257

Hugelius, G., Loisel, J., Chadburn, S., Jackson, R. B., Jones, M., MacDonald, G., Marushchak, M., Olefeldt, D., Packalen, M., Siewert, M. B., Treat, C., Turetsky, M., Voigt, C., \& Yu, Z. (2020). Large stocks of peatland carbon and nitrogen are vulnerable to permafrost thaw. Proceedings of the National Academy of Sciences, 117(34), 20438-20446. https://doi.org/10.1073/pnas.1916387117

Jassey, V. E., Chiapusio, G., Binet, P., Buttler, A., Laggoun-Défarge, F., Delarue, F., Bernard, N., Mitchell, E. A., Toussaint, M.-L., Francez, A.-J., \& Gilbert, D. (2013). Above- and belowground linkages in Sphagnum peatland: climate warming affects plant-microbial interactions. Global Change Biology, 19(3), 811-823. https://doi.org/10.1111/gcb.12075

Jassey, V. E. J., Gilbert, D., Binet, P., Toussaint, M.-L., \& Chiapusio, G. (2011). Effect of a temperature gradient on Sphagnum fallax and its associated living microbial communities: a study under controlled conditions. Canadian Journal of Microbiology, 57(3), 226-235. https://doi.org/10.1139/W10-116

Jassey, V. E. J., Reczuga, M. K., Zielińska, M., Słowińska, S., Robroek, B. J. M., Mariotte, P., Seppey, C. V. W., Lara, E., Barabach, J., Słowiński, M., Bragazza, L., Chojnicki, B. H., Lamentowicz, M., 
Mitchell, E. A. D., \& Buttler, A. (2018). Tipping point in plant-fungal interactions under severe drought causes abrupt rise in peatland ecosystem respiration. Global Change Biology, 24(3), 972-986. https://doi.org/10.1111/gcb.13928

Jassey, V. E. J., \& Signarbieux, C. (2019). Effects of climate warming on Sphagnum photosynthesis in peatlands depend on peat moisture and species-specific anatomical traits. Global Change Biology, 25(11), 3859-3870. https://doi.org/10.1111/gcb.14788

Jassey, V. E. J., Signarbieux, C., Hättenschwiler, S., Bragazza, L., Buttler, A., Delarue, F., Fournier, B., Gilbert, D., Laggoun-Défarge, F., Lara, E., T. E. Mills, R., Mitchell, E. A. D., Payne, R. J., \& Robroek, B. J. M. (2015). An unexpected role for mixotrophs in the response of peatland carbon cycling to climate warming. Scientific Reports, 5, 16931. https://doi.org/10.1038/srep16931

Jeffrey, S. ., Mantoura, R. F. ., \& Wright, S. . (1997). Phytoplankton pigments in oceanography. UNESCO Publishing.

Jia, L., Feng, X., Zheng, Z., Han, L., Hou, X., Lu, Z., \& Lv, J. (2015). Polymorphobacter fuscus sp. nov., isolated from permafrost soil, and emended description of the genus Polymorphobacter. International Journal of Systematic and Evolutionary Microbiology, 65(11), 3920-3925. https://doi.org/10.1099/ijsem.0.000514

Kalchev, R. K., Beshkova, M. B., Boumbarova, C. S., Tsvetkova, R. L., \& Sais, D. (1996). Some allometric and non-allometric relationships between chlorophyll-a and abundance variables of phytoplankton. Hydrobiologia, 341(3), 235-245. https://doi.org/10.1007/BF00014688

Krumins, J. A., van Oevelen, D., Bezemer, T. M., De Deyn, G. B., Hol, W. H. G., van Donk, E., de Boer, W., de Ruiter, P. C., Middelburg, J. J., Monroy, F., Soetaert, K., Thébault, E., van de Koppel, J., van Veen, J. A., Viketoft, M., \& van der Putten, W. H. (2013). Soil and Freshwater and Marine Sediment Food Webs: Their Structure and Function. BioScience, 63(1), 35-42. https://doi.org/10.1525/bio.2013.63.1.8 
Kulichevskaya, I. S., Danilova, O. V., Tereshina, V. M., Kevbrin, V. V., \& Dedysh, S. N. (2014). Descriptions of Roseiarcus fermentans gen. nov., sp. nov., a bacteriochlorophyll a-containing fermentative bacterium related phylogenetically to alphaproteobacterial methanotrophs, and of the family Roseiarcaceae fam. nov. International Journal of Systematic and Evolutionary Microbiology, 64(Pt 8), 2558-2565. https://doi.org/10.1099/ijs.0.064576-0

Lara, E., Mitchell, E. A. D., Moreira, D., \& López García, P. (2011). Highly Diverse and Seasonally Dynamic Protist Community in a Pristine Peat Bog. Protist, 162(1), 14-32. https://doi.org/10.1016/j.protis.2010.05.003

Lefcheck, J. S. (2016). piecewiseSEM: Piecewise structural equation modelling in $r$ for ecology, evolution, and systematics. Methods in Ecology and Evolution, 7(5), 573-579. https://doi.org/10.1111/2041-210X.12512

Leifeld, J., \& Menichetti, L. (2018). The underappreciated potential of peatlands in global climate change mitigation strategies. Nature Communications, 9(1), 1071. https://doi.org/10.1038/s41467-018-03406-6

Li, A., Stoecker, D. K., \& Adolf, J. E. (1999). Feeding, pigmentation, photosynthesis and growth of the mixotrophic dinoflagellate Gyrodinium galatheanum. Aquatic Microbial Ecology, 19(2), 163176. https://doi.org/10.3354/ame019163

Liang, C., Schimel, J. P., \& Jastrow, J. D. (2017). The importance of anabolism in microbial control over soil carbon storage. Nature Microbiology, 2(8), 1-6. https://doi.org/10.1038/nmicrobiol.2017.105

Lindo, Z., \& Gonzalez, A. (2010). The Bryosphere: An Integral and Influential Component of the Earth's Biosphere. Ecosystems, 13(4), 612-627. https://doi.org/10.1007/s10021-010-9336-3

Lynn, T. M., Ge, T., Yuan, H., Wei, X., Wu, X., Xiao, K., Kumaresan, D., Yu, S. S., Wu, J., \& Whiteley, A. S. (2017). Soil Carbon-Fixation Rates and Associated Bacterial Diversity and Abundance in Three Natural Ecosystems. Microbial Ecology, 73(3), 645-657. https://doi.org/10.1007/s00248-016-0890-x 
Mahé, F., Rognes, T., Quince, C., Vargas, C. de, \& Dunthorn, M. (2014). Swarm: robust and fast clustering method for amplicon-based studies. PeerJ, 2, e593. https://doi.org/10.7717/peerj.593

Maier, S., Tamm, A., Wu, D., Caesar, J., Grube, M., \& Weber, B. (2018). Photoautotrophic organisms control microbial abundance, diversity, and physiology in different types of biological soil crusts. The ISME Journal, 12(4), 1032-1046. https://doi.org/10.1038/s41396-018-0062-8

McMurdie, P. J., \& Holmes, S. (2013). phyloseq: An R Package for Reproducible Interactive Analysis and Graphics of Microbiome Census Data. PLOS ONE, 8(4), e61217. https://doi.org/10.1371/journal.pone.0061217

Mitchell, E. A. D., Gilbert, D., Buttler, A., Amblard, C., \& Grosvernier, P. (2003). Structure of Microbial Communities in SphagnumPeatlands and Effect of Atmospheric Carbon Dioxide Enrichment. Microbial Ecology, 46, 187-199.

Mitra, A., Flynn, K. J., Tillmann, U., Raven, J. A., Caron, D., Stoecker, D. K., Not, F., Hansen, P. J., Hallegraeff, G., Sanders, R., Wilken, S., McManus, G., Johnson, M., Pitta, P., Våge, S., Berge, T., Calbet, A., Thingstad, F., Jeong, H. J., ... Lundgren, V. (2016). Defining Planktonic Protist Functional Groups on Mechanisms for Energy and Nutrient Acquisition: Incorporation of Diverse Mixotrophic Strategies. Protist, 167(2), 106-120. https://doi.org/10.1016/j.protis.2016.01.003

Myers, B., Webster, K. L., Mclaughlin, J. W., \& Basiliko, N. (2012). Microbial activity across a boreal peatland nutrient gradient: the role of fungi and bacteria. Wetlands Ecology and Management, 20(2), 77-88. https://doi.org/10.1007/s11273-011-9242-2

Nichols, J. E., \& Peteet, D. M. (2019). Rapid expansion of northern peatlands and doubled estimate of carbon storage. Nature Geoscience, 12(11), 917-921. https://doi.org/10.1038/s41561-0190454-z 
Ogawa, T., Misumi, M., \& Sonoike, K. (2017). Estimation of photosynthesis in cyanobacteria by pulseamplitude modulation chlorophyll fluorescence: problems and solutions. Photosynthesis Research, 133(1), 63-73. https://doi.org/10.1007/s11120-017-0367-x

Okamura, K., Hisada, T., Kanbe, T., \& Hiraishi, A. (2009). Rhodovastum atsumiense gen. nov., sp. nov., a phototrophic alphaproteobacterium isolated from paddy soil. The Journal of General and Applied Microbiology, 55(1), 43-50. https://doi.org/10.2323/jgam.55.43

Oliverio, A. M., Geisen, S., Delgado-Baquerizo, M., Maestre, F. T., Turner, B. L., \& Fierer, N. (2020). The global-scale distributions of soil protists and their contributions to belowground systems. Science Advances, 6(4), eaax8787. https://doi.org/10.1126/sciadv.aax8787

Olson, R. J., Zettler, E. R., \& Anderson, O. K. (1989). Discrimination of eukaryotic phytoplankton cell types from light scatter and autofluorescence properties measured by flow cytometry. Cytometry, 10(5), 636-643. https://doi.org/10.1002/cyto.990100520

Padfield, D., Buckling, A., Warfield, R., Lowe, C., \& Yvon-Durocher, G. (2018). Linking phytoplankton community metabolism to the individual size distribution. Ecology Letters, 21(8), 1152-1161. https://doi.org/10.1111/ele.13082

Quast, C., Pruesse, E., Yilmaz, P., Gerken, J., Schweer, T., Yarza, P., Peplies, J., \& Glöckner, F. O. (2013). The SILVA ribosomal RNA gene database project: improved data processing and webbased tools. Nucleic Acids Research, 41(D1), D590-D596. https://doi.org/10.1093/nar/gks1219

R Core Team. (2019). R: A language and environment for statistical computing. $R$ Foundation for Statistical Computing, Vienna, Austria. Available at: URL http://www.R-project.org/.

Reczuga, M. K., Lamentowicz, M., Mulot, M., Mitchell, E. A. D., Buttler, A., Chojnicki, B., Słowiński, M., Binet, P., Chiapusio, G., Gilbert, D., Słowińska, S., \& Jassey, V. E. J. (2018). Predator-prey mass ratio drives microbial activity under dry conditions in Sphagnum peatlands. Ecology and Evolution, 8(11), 5752-5764. https://doi.org/10.1002/ece3.4114 
Reczuga, M. K., Seppey, C. V. W., Mulot, M., Jassey, V. E. J., Buttler, A., Słowińska, S., Słowiński, M., Lara, E., Lamentowicz, M., \& Mitchell, E. A. D. (2020). Assessing the responses of Sphagnum micro-eukaryotes to climate changes using high throughput sequencing. PeerJ, 8, e9821. https://doi.org/10.7717/peerj.9821

Řeháková, K., Čapková, K., Dvorský, M., Kopecký, M., Altman, J., Šmilauer, P., \& Doležal, J. (2017). Interactions between soil phototrophs and vascular plants in Himalayan cold deserts. Soil Biology and Biochemistry, 115, 568-578. https://doi.org/10.1016/j.soilbio.2017.05.020

Rober, A. R., Wyatt, K. H., Stevenson, R. J., \& Turetsky, M. R. (2014). Spatial and temporal variability of algal community dynamics and productivity in floodplain wetlands along the Tanana River, Alaska. Freshwater Science, 33(3), 765-777. https://doi.org/10.1086/676939

Robroek, B. J. M., Jassey, V. E. J., Payne, R. J., Martí, M., Bragazza, L., Bleeker, A., Buttler, A., Caporn, S. J. M., Dise, N. B., Kattge, J., Zając, K., Svensson, B. H., van Ruijven, J., \& Verhoeven, J. T. A. (2017). Taxonomic and functional turnover are decoupled in European peat bogs. Nature Communications, 8(1), 1161. https://doi.org/10.1038/s41467-017-01350-5

Robroek, B. J. M., Schouten, M. G. C., Limpens, J., Berendse, F., \& Poorter, H. (2009). Interactive effects of water table and precipitation on net $\mathrm{CO} 2$ assimilation of three co-occurring Sphagnum mosses differing in distribution above the water table. Global Change Biology, 15(3), 680-691. https://doi.org/10.1111/j.1365-2486.2008.01724.x

Rognes, T., Flouri, T., Nichols, B., Quince, C., \& Mahé, F. (2016). VSEARCH: a versatile open source tool for metagenomics. PeerJ, 4, e2584. https://doi.org/10.7717/peerj.2584

Rossi, F., Olguín, E. J., Diels, L., \& De Philippis, R. (2015). Microbial fixation of CO2 in water bodies and in drylands to combat climate change, soil loss and desertification. New Biotechnology, 32(1), 109-120. https://doi.org/10.1016/j.nbt.2013.12.002

Schuurmans, R. M., Alphen, P. van, Schuurmans, J. M., Matthijs, H. C. P., \& Hellingwerf, K. J. (2015). Comparison of the Photosynthetic Yield of Cyanobacteria and Green Algae: Different 
Methods Give Different Answers. PLOS ONE, 10(9), e0139061. https://doi.org/10.1371/journal.pone.0139061

Singh, B. K., Bardgett, R. D., Smith, P., \& Reay, D. S. (2010). Microorganisms and climate change: terrestrial feedbacks and mitigation options. Nature Reviews Microbiology, 8(11), 779-790. https://doi.org/10.1038/nrmicro2439

Stoler, A. B., \& Relyea, R. A. (2011). Living in the litter: the influence of tree leaf litter on wetland communities. Oikos, 120(6), 862-872. https://doi.org/10.1111/j.1600-0706.2010.18625.x

Sytiuk, A., Céréghino, R., Hamard, S., Delarue, F., Dorrepaal, E., Küttim, M., Lamentowicz, M., Pourrut, B., Robroek, B. J., Tuittila, E.-S., \& Jassey, V. E. J. (2020). Morphological and biochemical responses of Sphagnum mosses to environmental changes [Preprint]. Ecology. https://doi.org/10.1101/2020.10.29.360388

Sytiuk A., Céréghino R., Hamard S., Delarue F., et al. (2021) Predicting the structure and functions of peatland microbial communities from Sphagnum phylogeny, anatomical traits and metabolites. Journal of Ecology, under revision.

Tanabe, A. S., Nagai, S., Hida, K., Yasuike, M., Fujiwara, A., Nakamura, Y., Takano, Y., \& Katakura, S. (2016). Comparative study of the validity of three regions of the 18S-rRNA gene for massively parallel sequencing-based monitoring of the planktonic eukaryote community. Molecular Ecology Resources, 16(2), 402-414. https://doi.org/10.1111/1755-0998.12459

Tang, K.-H., Tang, Y. J., \& Blankenship, R. E. (2011). Carbon Metabolic Pathways in Phototrophic Bacteria and Their Broader Evolutionary Implications. Frontiers in Microbiology, 2. https://doi.org/10.3389/fmicb.2011.00165

Thormann, M. N. (2006). Diversity and function of fungi in peatlands: A carbon cycling perspective. Canadian Journal of Soil Science, 86(Special Issue), 281-293. https://doi.org/10.4141/S05082 
Tian, W., Wang, H., Xiang, X., Wang, R., \& Xu, Y. (2019). Structural Variations of Bacterial Community Driven by Sphagnum Microhabitat Differentiation in a Subalpine Peatland. Frontiers in Microbiology, 10. https://doi.org/10.3389/fmicb.2019.01661

Turetsky, M. R. (2003). The Role of Bryophytes in Carbon and Nitrogen Cycling. The Bryologist, 106(3), 395-409. JSTOR.

van Breemen, N. (1995). How Sphagnum bogs down other plants. Trends in Ecology \& Evolution, 10(7), 270-275. https://doi.org/10.1016/0169-5347(95)90007-1

Wang, Y., \& Qian, P.-Y. (2009). Conservative Fragments in Bacterial 165 rRNA Genes and Primer Design for 16S Ribosomal DNA Amplicons in Metagenomic Studies. PLOS ONE, 4(10), e7401. https://doi.org/10.1371/journal.pone.0007401

Ward, B. A., \& Follows, M. J. (2016). Marine mixotrophy increases trophic transfer efficiency, mean organism size, and vertical carbon flux. Proceedings of the National Academy of Sciences, 113(11), 2958-2963. https://doi.org/10.1073/pnas.1517118113

Weisse, T., Müller, H., Pinto-Coelho, R. M., Schweizer, A., Springmann, D., \& Baldringer, G. (1990). Response of the microbial loop to the phytoplankton spring bloom in a large prealpine lake. Limnology and Oceanography, 35(4), 781-794. https://doi.org/10.4319/lo.1990.35.4.0781

Wilken, S., Huisman, J., Naus-Wiezer, S., \& Donk, E. V. (2013). Mixotrophic organisms become more heterotrophic with rising temperature. Ecology Letters, 16(2), 225-233. https://doi.org/10.1111/ele.12033

Worden, A. Z., Follows, M. J., Giovannoni, S. J., Wilken, S., Zimmerman, A. E., \& Keeling, P. J. (2015). Rethinking the marine carbon cycle: Factoring in the multifarious lifestyles of microbes. Science, 347(6223). https://doi.org/10.1126/science.1257594

Wyatt, K. H., Bange, J. S., Fitzgibbon, A. S., Bernot, M. J., \& Rober, A. R. (2014). Nutrients and temperature interact to regulate algae and heterotrophic bacteria in an Alaskan poor fen peatland. Canadian Journal of Fisheries and Aquatic Sciences, 72(3), 447-453. https://doi.org/10.1139/cjfas-2014-0425 
Wyatt, K. H., \& Turetsky, M. R. (2015). Algae alleviate carbon limitation of heterotrophic bacteria in a boreal peatland. Journal of Ecology, 103(5), 1165-1171. https://doi.org/10.1111/13652745.12455

Wyatt, K. H., Turetsky, M. R., Rober, A. R., Giroldo, D., Kane, E. S., \& Stevenson, R. J. (2012). Contributions of algae to GPP and DOC production in an Alaskan fen: effects of historical water table manipulations on ecosystem responses to a natural flood. Oecologia, 169(3), 821-832. https://doi.org/10.1007/s00442-011-2233-4

Yu, Z. C. (2012). Northern peatland carbon stocks and dynamics: a review. Biogeosciences, 9(10), 4071-4085. https://doi.org/10.5194/bg-9-4071-2012

Yurkov, V., Gad'on, N., \& Drews, G. (1993). The major part of polar carotenoids of the aerobic bacteria Roseococcus thiosulfatophilus RB3 and Erythromicrobium ramosum E5 is not bound to the bacteriochlorophyll a-complexes of the photosynthetic apparatus. Archives of Microbiology, 160(5). https://doi.org/10.1007/BF00252223

Yvon-Durocher, G., Allen, A. P., Cellamare, M., Dossena, M., Gaston, K. J., Leitao, M., Montoya, J. M., Reuman, D. C., Woodward, G., \& Trimmer, M. (2015). Five Years of Experimental Warming Increases the Biodiversity and Productivity of Phytoplankton. PLOS Biology, 13(12), e1002324. https://doi.org/10.1371/journal.pbio.1002324

Zancan, S., Trevisan, R., \& Paoletti, M. G. (2006). Soil algae composition under different agroecosystems in North-Eastern Italy. Agriculture, Ecosystems \& Environment, 112(1), 1-12. https://doi.org/10.1016/j.agee.2005.06.018

Zeng, Y., Feng, F., Medova, H., Dean, J., \& Kobli ek, M. (2014). Functional type 2 photosynthetic reaction centers found in the rare bacterial phylum Gemmatimonadetes. Proceedings of the National Academy of Sciences, 111(21), 7795-7800. https://doi.org/10.1073/pnas.1400295111 
966 Fig. 1: Geographic locations of the five European peatlands and structure of microbial prokaryotic and 967 eukaryotic communities (A). NMDS of the communities of phototrophic bacteria (B) and phototrophic 968 protists based on phototrophic OTUs (C).

A

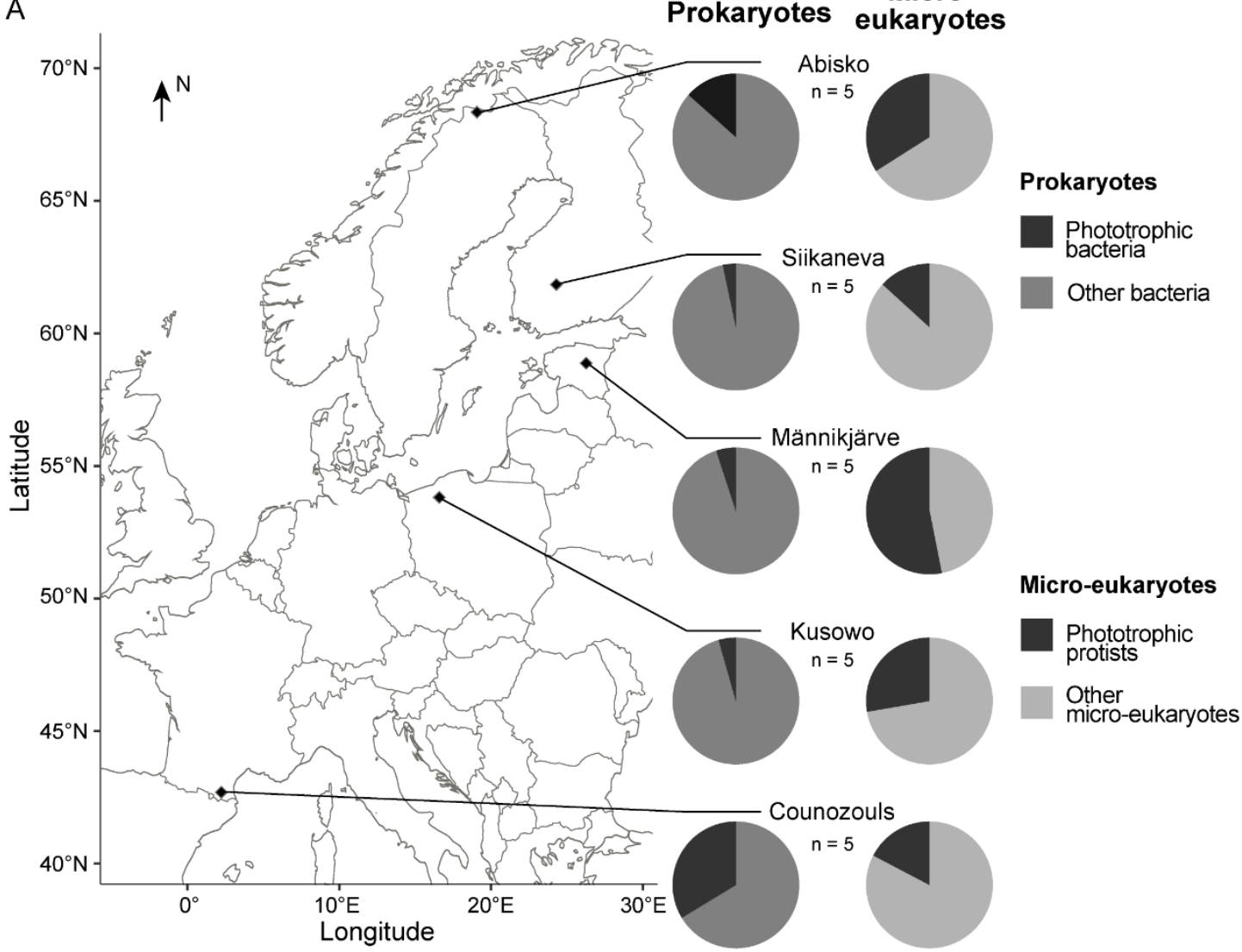

B Phototrophic bacteria

C Phototrophic protists
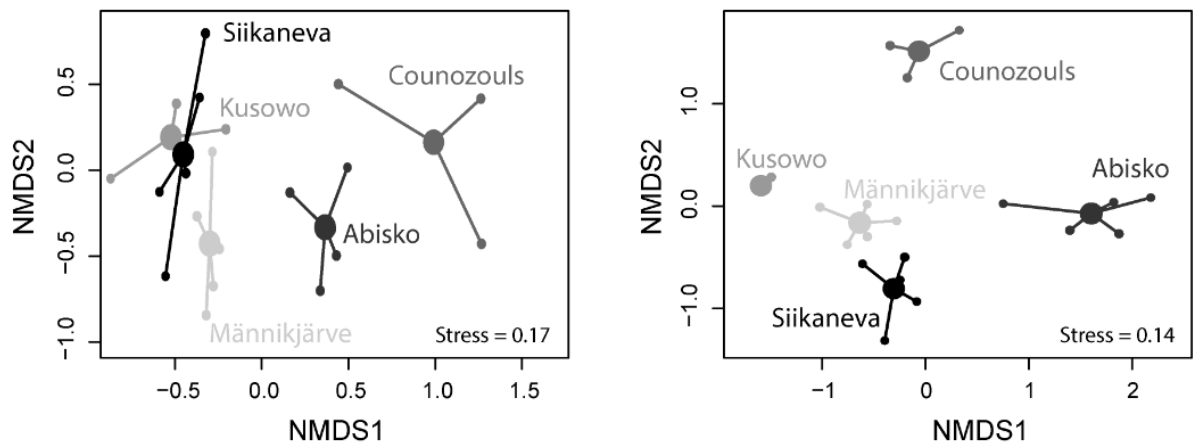
Fig. 2: Phylogenetic tree, relative abundance (A), and diversity (B) of the phototrophic OTUs identified

971 in the five peatland sites along the latitudinal gradient. Phototrophic OTUs include endosymbiotic mixotrophs (e.g., Hyalosphenia papilio, Lobosa). Relative abundance of phototrophic OTUs is ( $n=5$ replicates), while points represent the mean value in each site.

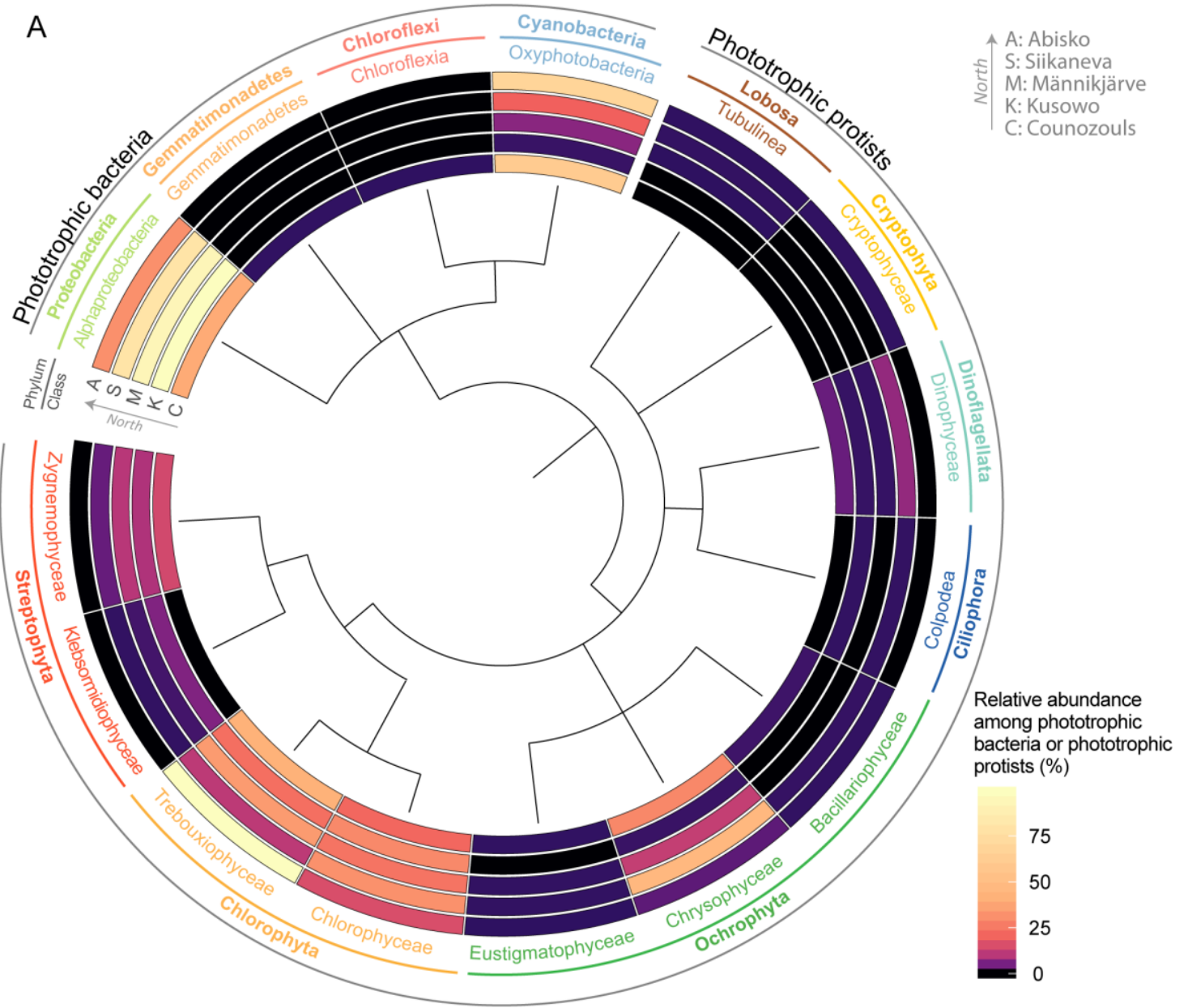

B
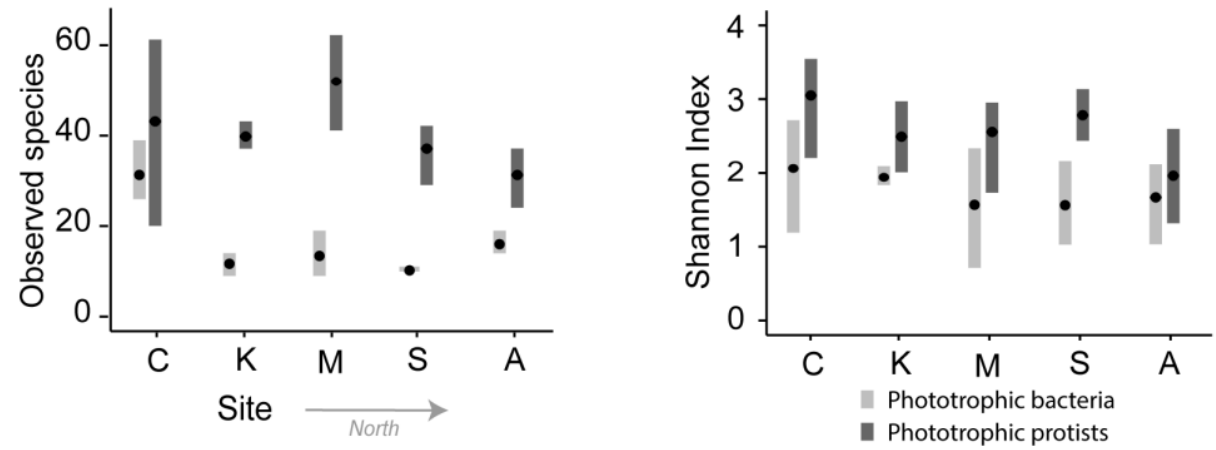
Fig. 3: Generalised dissimilarity modelling and taxonomic turnover along environmental gradients.

979 Relationship between compositional dissimilarity between site pairs (species turnover or beta-

980 diversity) and their predicted environmental dissimilarity, for phototrophic bacteria communities (A),

981 and for phototrophic protists communities (C). Partial regression fits (Model-fitted-I-splines) for factors

982 significantly associated with phototrophic bacteria species turnover (B), and phototrophic protist

983 species turnover (D). Factors identified with a significant effect on species turnover were Plant

\section{Phototrophic bacteria}

A

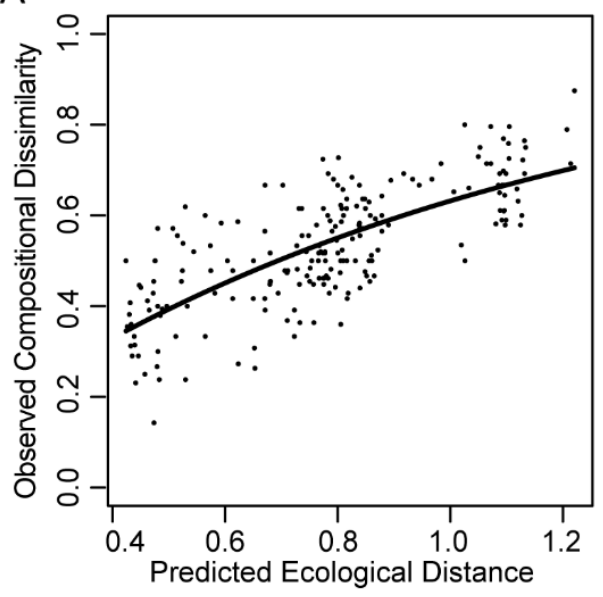

B

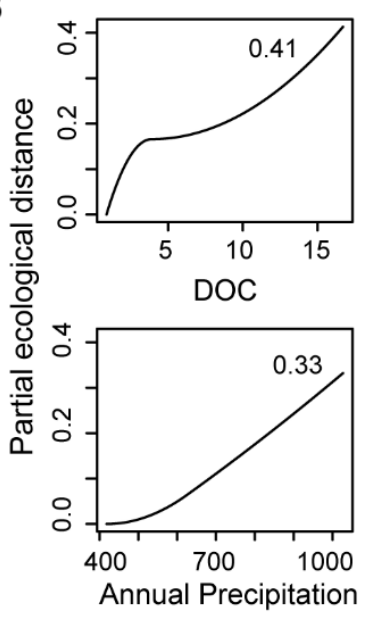

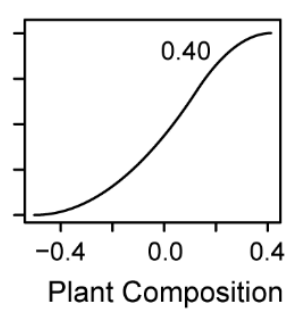

Plant Composition

Phototrophic protists

C

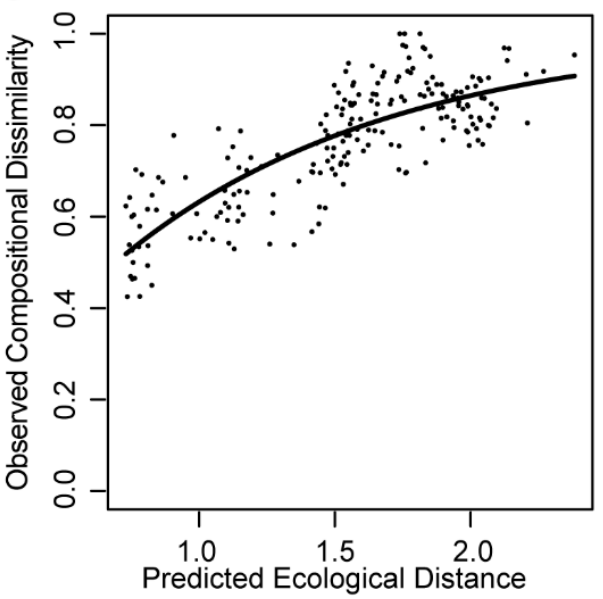

D
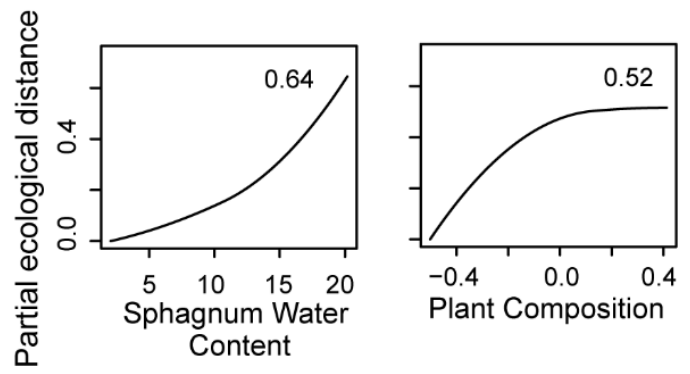
Fig. 4: Abundance of all phototrophs (A) and large mixotrophs (body size $>40 \mu \mathrm{m}$ ) $(\mathbf{B})$ in the five

990 peatlands. Community-weighted mean body size of phototrophic microbes (C) and total phototrophic

991 biomass (D) in the five peatlands. Chlorophyll $a$ cellular content of phototrophs in the five peatlands

992 (E). Photosynthetic rates (electron transport rate -ETR- per cell) of phototrophs in the five peatlands

993 (F). Error bars present standard error ( $\mathrm{n}=5$ replicates). Significant differences $(P<0.05)$ are indicated

by different letters above bars. C: Counozouls; K: Kusowo; M: Männikjärve; S: Siikaneva; A: Abisko.

A

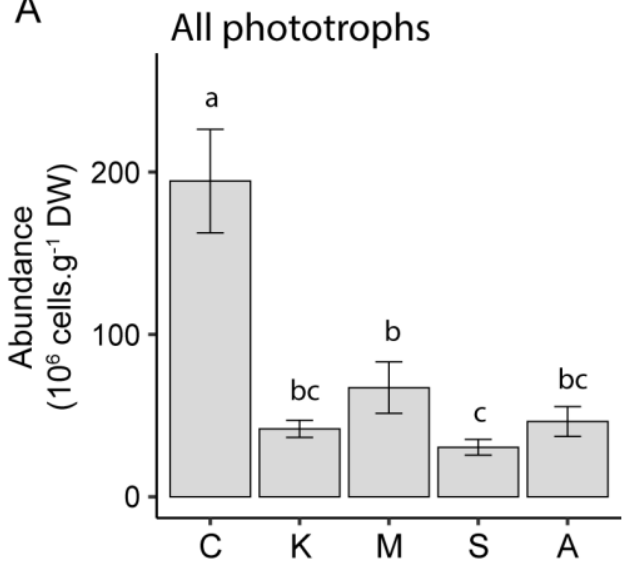

C

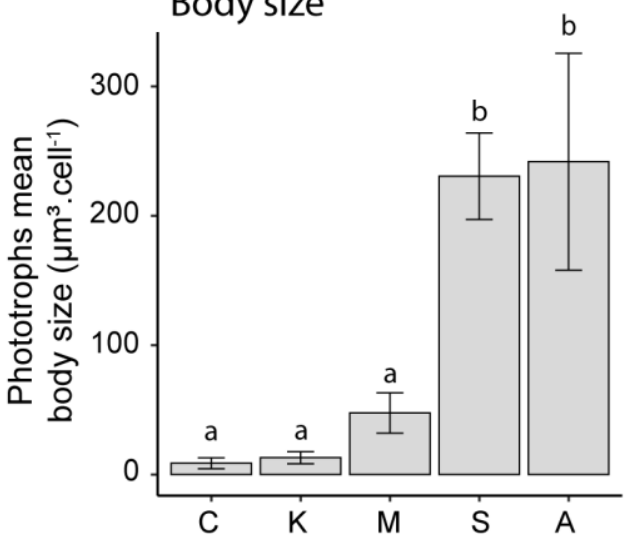

E

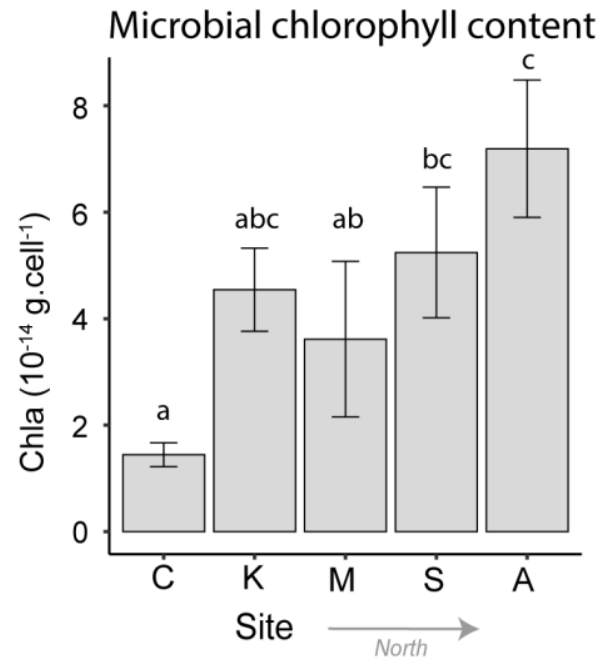

B

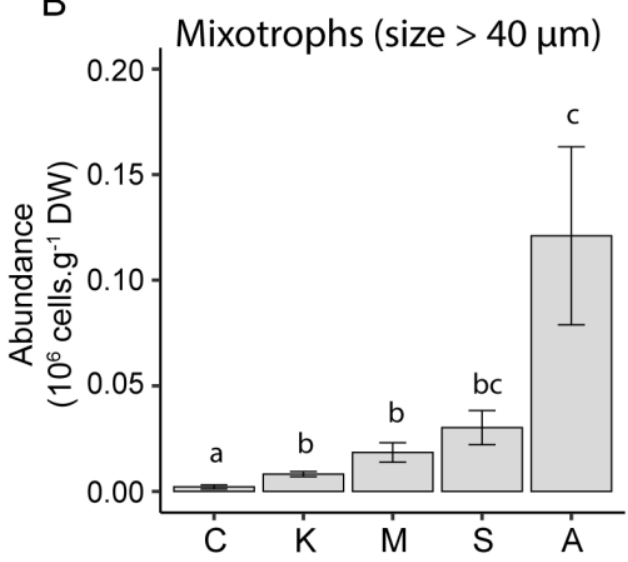

D Total phototrophic biomass

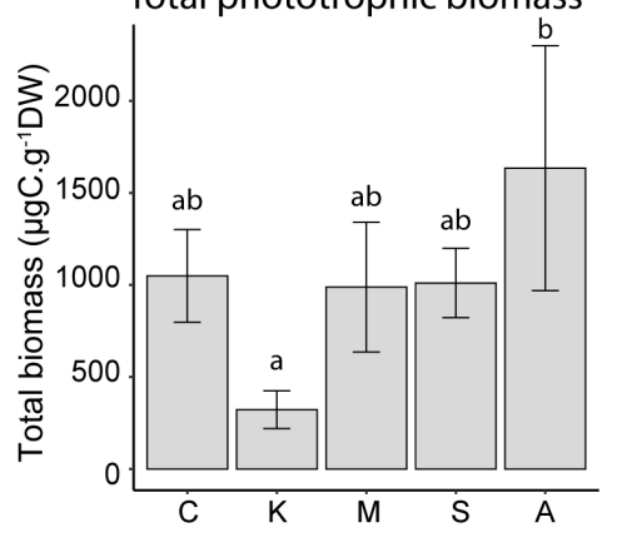

F Microbial photosynthetic rate

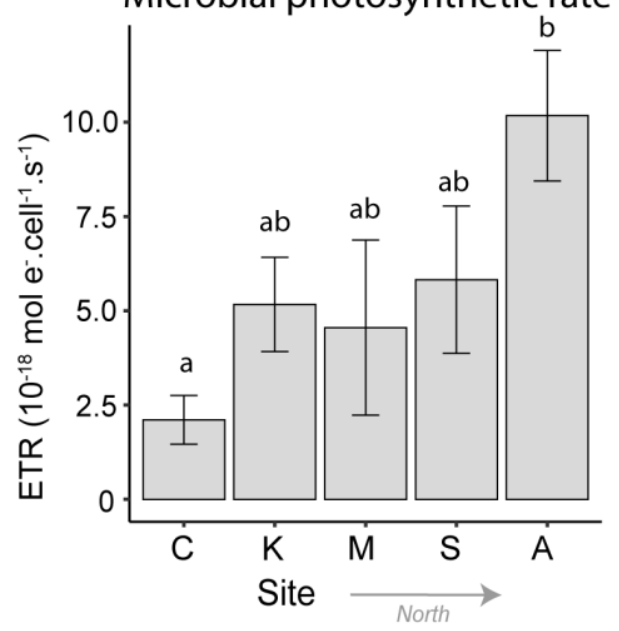


Fig. 5: Microbial (light grey) and bryosphere (dark grey) C fixation rates, expressed per surface unit (A) or normalised by the chlorophyll $a$ content (B); and contribution of microorganisms to bryosphere $\mathrm{C}$

998 fixation (C) in the five peatlands. Bars range between minimum and maximum values ( $\mathrm{n}=5$ replicates).

999 Points represent the mean values at each site, while the dotted line in panel (C) represent the mean 1000 values across sites. C: Counozouls; K: Kusowo; M: Männikjärve; S: Siikaneva; A: Abisko.

A Carbon fluxes per surface unit
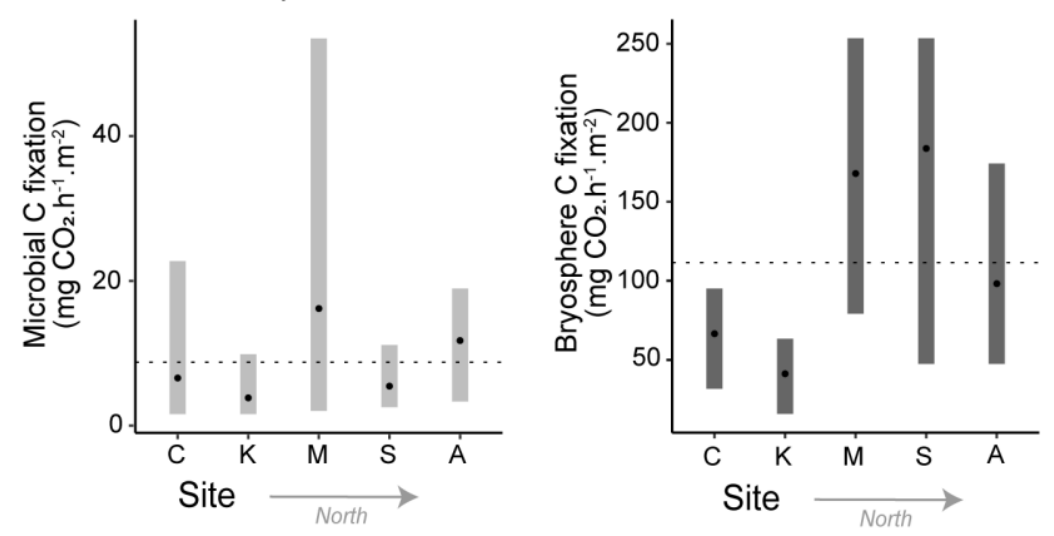

B Carbon fluxes per chlorophyll content
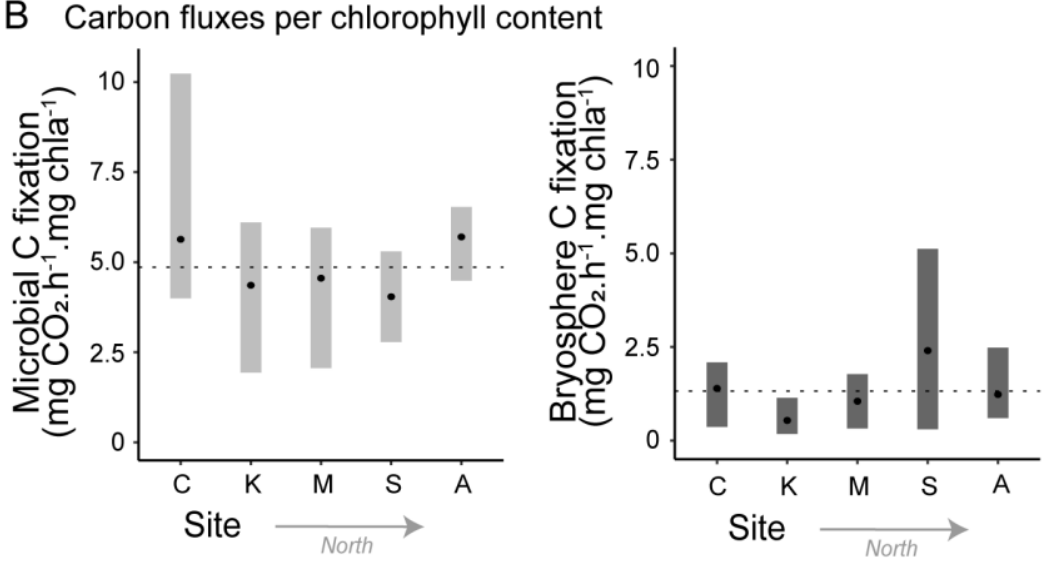

C Microbial contribution to bryosphere fluxes

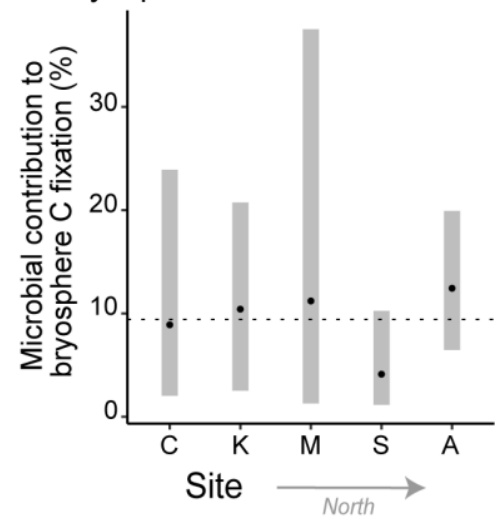


Fig. 6: Structural equation model (SEM) of the correlations between the structure of phototrophic 1003 microbial communities, their allometric and metabolic features and microbial $\mathrm{C}$ fixation. Numbers in the boxes indicate the percentage of variance explained by the model (adjusted R-squared), while numbers along the arrows indicate the weight of the path relationship $(* 0.01<P<0.05$;

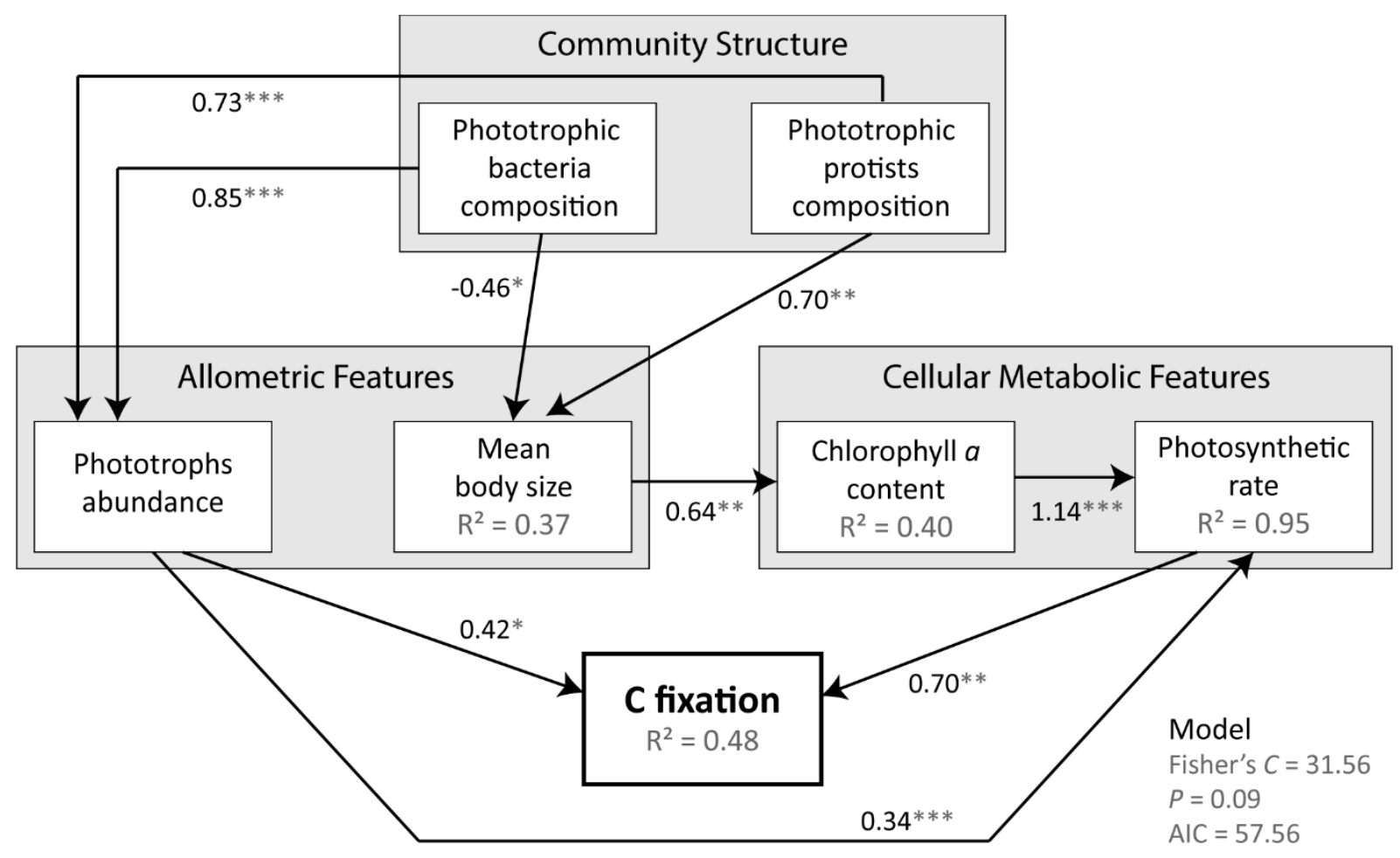

